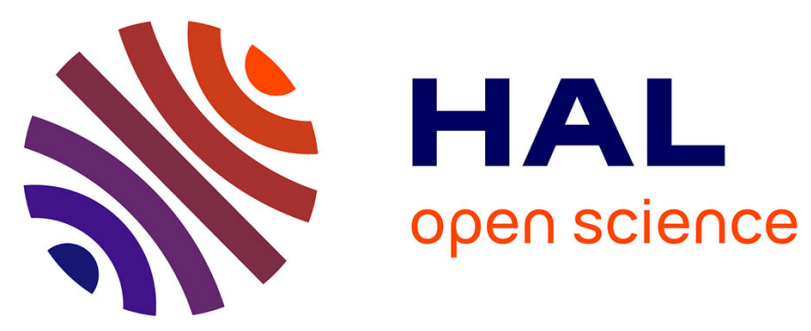

\title{
Lithogeochemical, mineralogical analyses and oxygen-hydrogen isotopes of the Hercynian Koudiat Aïcha massive sulphide deposit, Morocco
}

\author{
F. Lotfi, Abdelhay Belkabir, S. Brunet, Eric Marcoux
}

\section{- To cite this version:}

F. Lotfi, Abdelhay Belkabir, S. Brunet, Eric Marcoux. Lithogeochemical, mineralogical analyses and oxygen-hydrogen isotopes of the Hercynian Koudiat Aïcha massive sulphide deposit, Morocco. Journal of African Earth Sciences, 2010, 56 (4-5), pp.150-166. 10.1016/j.jafrearsci.2009.06.005 . insu00462640

HAL Id: insu-00462640

https://hal-insu.archives-ouvertes.fr/insu-00462640

Submitted on 11 Apr 2011

HAL is a multi-disciplinary open access archive for the deposit and dissemination of scientific research documents, whether they are published or not. The documents may come from teaching and research institutions in France or abroad, or from public or private research centers.
L'archive ouverte pluridisciplinaire HAL, est destinée au dépôt et à la diffusion de documents scientifiques de niveau recherche, publiés ou non, émanant des établissements d'enseignement et de recherche français ou étrangers, des laboratoires publics ou privés. 


\title{
Lithogeochemical, mineralogical analyses and oxygen-hydrogen isotopes of the Hercynian Koudiat Aïcha massive sulphide deposit, Morocco
}

\author{
F. Lotfi ${ }^{\underline{a}}$, A. Belkabir ${ }^{a}$, S. Brunet ${ }^{\underline{b}}$, A.C. Brown ${ }^{\mathrm{c}}$ and E. Marcoux $^{\mathrm{d}}$ \\ ${ }^{a}$ Université Cadi Ayyad, Laboratoire Géoressources, Faculté des Sciences et Techniques, \\ Marrakech, BP. 549, Marrakech, Morocco \\ ${ }^{\mathrm{b}}$ Mine Draa Sfar, Marrakech, Morocco \\ ${ }^{\mathrm{c}}$ Dept. of Civil, Geological and Mining Eng., École Polytechnique de Montréal, Canada \\ ${ }^{\mathrm{d}}$ Institut des Sciences de la Terre d'Orléans, Université d'Orléans, Orléans, France
}

\begin{abstract}
Koudiat Aïcha is a Visean stratiform, volcanogenic massive sulphide (VMS) zinc-copperlead deposit, situated northwest of Marrakech, within the Central Domain of the Jebilet massif of the Western Moroccan Meseta. The Central Domain is formed mainly of sedimentary (argillite, siltstone, sandstone, carbonate) and magmatic (gabbro and rhyodacite) rocks that host numerous massive sulphide deposits (e.g., Koudiat Aïcha, Kettara and Draa Sfar) in a thick grayish argillite sequence (rhythmic metapelite). The deposit is stratabound and consists of highly deformed, sheet-like lenses of massive sulphide located structurally on the eastern flank of a large anticline. Prior to metamorphism, the country rocks were subjected to hydrothermal alteration which is particularly pronounced in the immediate vicinity of the sulphide deposits where chloritization and sericitization are prevalent. Hydrothermal alteration extends into both the stratigraphic footwall and the stratigraphic hanging wall. The footwall lacks an obvious pipe zone (sulphide stringers or vent complex) beneath the sulphide mineralization, but is characterized by an increase in the modal proportion of Mg-chlorite and by the breakdown of feldspar and sericite. Chloritization, the most extensive and readily recognizable alteration useful in mineral exploration, is evident for more than $60 \mathrm{~m}$ above the subcropping sulphide deposits. The hanging wall rocks show a pervasive sericitization (over $30 \mathrm{~m}$ wide) and a weak chlorite alteration accompanied by disseminated nodules of pyrrhotite stretched parallel to the $S_{1}$ foliation. Because chlorite and sericite are metamorphic minerals that also occur in unaltered rocks surrounding the sulphide deposits, abundant $\mathrm{Mg}$-rich chlorite and the absence of feldspar in the footwall are used to distinguish hydrothermal alteration facies from metamorphic facies. The chlorite geothermometer reveals temperatures between 250 and $330^{\circ} \mathrm{C}$. Higher temperatures (up to $300{ }^{\circ} \mathrm{C}$ ) are associated with chlorite located in and adjacent to sulphide mineralization, whereas lower temperatures correlate with distal chlorite in both the footwall and hanging wall rocks.
\end{abstract}

Chemical trends in altered footwall rocks are shown by absolute mass gains for $\mathrm{Fe}_{2} \mathrm{O}_{3 \text { total }}$, $\mathrm{MnO}$ and $\mathrm{MgO}$, by absolute mass losses for $\mathrm{CaO}, \mathrm{K}_{2} \mathrm{O}$ and $\mathrm{Na}_{2} \mathrm{O}$, and by a moderate loss in $\mathrm{SiO}_{2}$. Oxygen and hydrogen isotope compositions of Koudiat Aïcha lithofacies (6.2-12.4\%o for oxygen and $-51 \%$ to $-36 \%$ for hydrogen) have also been used to determine the temperature and origin of metalliferous fluids. The couple plagioclase-amphibole of gabbros provides equilibrium temperatures between 310 and $380^{\circ} \mathrm{C}$ and suggests that the heat source for the ore-forming fluid system may have been igneous. On the other hand, oxygen and hydrogen isotope ratios cluster between normal values for sedimentary and magmatic rocks, suggesting a magmatic-metamorphic origin for the ore fluid. 
Keywords: Massive sulphide; Hydrothermal alteration; Lithogeochemistry; Geothermometers; Oxygen and hydrogen isotopes; Hercynian; Koudiat Aïcha; Morocco

\section{Introduction}

The volcanogenic Koudiat Aïcha massive sulphide deposit is situated in the Central Domain of the Hercynian Jebilet massif, $32 \mathrm{~km}$ northwest of Marrakech, Morocco (Fig. 1). It consists of closely-spaced, thin sulphide lenses within mainly siliciclastic sedimentary strata (argillite, sandstone, siltstone, \pm carbonate) intercalated with gabbro sills and minor rhyodacite flows and tuffs.

As described by Lotfi et al. (2008), the sulphide mineralization consists principally of several lenses of massive to semi-massive pyrrhotite, 1-20 m in thickness, enclosed by a large halo of asymmetrically disseminated sulphides. The ore sulphides are pyrrhotite, along with lesser amounts of sphalerite, chalcopyrite, arsenopyrite, galena, pyrite and stannite. Well-preserved sedimentary structures in the sulphide mineralization and the conformability of sulphide lenses to the enclosing sedimentary bedding suggest that the sulphides formed syngenetically or by very early diagenetic replacement of earlier syngenetic sulphides. Lead isotope analyses $\left({ }^{206} \mathrm{~Pb} /{ }^{204} \mathrm{~Pb}\right.$ averaging 18.27) suggest that the metals of the Koudiat Aïcha deposit might have been derived from their footwall volcano-sedimentary host rocks, whereas sulphur isotope ratios $\left(\delta^{34} \mathrm{~S}=-7.5 \%\right.$ to $-10.5 \%$ indicate a sedimentary source involving bacterial sulphate reduction.

In this paper, we used new geochemical, isotopic $(\mathrm{O}-\mathrm{H})$ and mineral composition data to characterize the hydrothermal alteration around the sulphide deposit. We focus on the petrographic alteration and chemical changes related to sulphide deposition and discuss the thermal conditions of massive sulphide deposition. Based on its dominant host lithofacies (siliciclastic sedimentary rocks and gabbros), the elongate and tabular configuration of the sulphide zone, the ore mineralogy (chalcopyrite-pyrite-pyrrhotite and lesser sphalerite and galena) and the absence of a hydrothermal pipe, the Koudiat Aïcha sulphide deposit has been interpreted as a probable Besshi-type mineralization.

\section{Geological background}

The Koudiat Aïcha deposit crops out along a $1.5 \mathrm{~km}$-long north-south trend within Visean Carboniferous sedimentary and magmatic rocks in the middle of the Central Domain of the Jebilet massif, Morocco (Fig. 1). The Central Domain is characterized by siliciclastic sedimentary strata, including greyish argillites (70-80\%) interpreted by Beauchamp et al. (1991) as representing an anoxic depositional environment. The argillites are intercalated with siltstone and sandstone layers and with minor rhyodacite lava flows and tuffs, all of which are cut by gabbroic dikes and sills (10-15\%). The principal lithofacies and their petrographic descriptions are presented in Table 1, as well as in Lotfi et al. (2008). All lithologies have undergone greenschist-facies metamorphism, resulting in the formation of abundant sericite, chlorite (ripidolite to pycnochlorite), quartz and epidote.

In the study area, the local stratigraphy forms part of a homoclinal succession, with northsouth strikes and steep dips to the east (Fig. 2), part of a large anticlinal megastructure, $\mathrm{P}_{1}$. The opening and filling of the Devono-Carboniferous basin ([Huvellin, 1977], [Bordonaro, 1983], [Beauchamp, 1984] and [Beauchamp et al., 1991]) is followed by two deformation 
events $\left(\mathrm{D}_{1 \mathrm{KA}}, \mathrm{D} 2 \mathrm{KA}\right)$. These are correlated with a regional $\mathrm{D}_{1}$ deformation of the Central Domain, defined by an east-west compression which produced a penetrative $\mathrm{S}_{1}$ schistosity subparallel to the $S_{0}$ stratification and north-trending $P_{1}$ folds. The development of the $S_{1}$ schistosity was followed by a well-marked, local $\mathrm{S}_{2}$ crenulation schistosity. The $\mathrm{D}_{2 \mathrm{KA}}$ event was late and is characterized by a brittle, post-schistosity deformation which represents a lateto post-Hercynian tectonic episode. It is also characterized by fracture schistosity $\mathrm{S}_{3}$ kinkbands and N55 to $70^{\circ}$-striking dextral strike-slip faults (Bordonaro, 1983).

The base-metal sulphide mineralization is characterized at surface by a well-developed gossan extending over an area exceeding $120 \mathrm{~m}$ in its north-south length and $15 \mathrm{~m}$ in width. From its projected extensions at depth, the sulphide mineralization is seen to be located on the eastern flank of a $\mathrm{P}_{1}$ anticline dipping steeply to the east (Lotfi et al., 2008), and to be formed mainly of $N-S$ trending pyrrhotitic lenses measuring decameters in length and metres in thickness. Sulphide lenses generally increase in size with depth and may attain widths of 20-25 m (Fig. 2). The base-metal contents vary widely within and between individual mineralized lenses, generally with $\mathrm{Zn}>\mathrm{Pb}>\mathrm{Cu}$. The geological resources are estimated at between 3 and 5 million tonnes averaging $3 \% \mathrm{Zn}, 1 \% \mathrm{~Pb}$ and $0.6 \% \mathrm{Cu}$.

From the relative proportions of the principal sulphides, the structure and sulphide textures may be divided into four assemblages: (1) massive mineralization with pyrrhotite-(sphaleritegalena-chalcopyrite-pyrite); (2) banded sphalerite- and galena-rich mineralization; (3) pyrrhotite-chalcopyrite "stringer" mineralization; and (4) rhythmically bedded, barren (dominantly pyrrhotite) mineralization.

\section{Geochemistry}

\subsection{Sampling and analytical techniques}

For the geochemical study of the deposit, 42 representative samples were selected from diamond drill cores, supplemented by samples from outcrops. Diamond drill cores were used specifically for studying the hydrothermal alteration of the host argillite sequences below and above the sulphide bodies. Chemical analyses were carried out using standard techniques. All samples were crushed in chrome steel ball mills and powdered in an agate shatter box at the Laboratoire Géoressources, Université de Marrakech, Morocco (Table 2). Samples were analyzed for major and trace elements at the Geochemical Laboratories of the Department of Earth and Planetary Sciences, McGill University, Canada; major elements were analyzed by $\mathrm{X}$-ray fluorescence spectroscopy (XRF), whereas trace and rare-earth elements were analyzed by instrumental neutron activation analysis (INAA). Mineral compositions were determined on a CAMECA SX-50 electronic microprobe at the BRGM/ISTO laboratory, Orleans, France (Table $3 a$ and Table $3 b$ ).

\subsection{Primary geochemical features}

All rocks of the Koudiat Aïcha are deformed and altered as a result of regional metamorphism and hydrothermal alteration. To constrain the chemical composition and magmatic affinities of the sedimentary and volcano-plutonic successions, we used diagrams involving immobile elements such as $\mathrm{Al}, \mathrm{Ti}, \mathrm{Nb}, \mathrm{V}, \mathrm{Ga}, \mathrm{Zr}, \mathrm{Cr}, \mathrm{HFSE}$ and $\mathrm{Y}$. In several mining districts, these elements have been found to be useful tools to ascertain the primary chemical character of the 
now altered rocks ([Ludden et al., 1982], [Lesher et al., 1986], [MacLean and Kranidiotis, 1987] and [Jenner, 1996]).

The principal sedimentary lithologies in the deposit consist of rhythmically interbedded dark argillites, silty green phyllites and quartz-rich sandstones that were contemporaneous with or pre-dated the deposition of ore-stage sulphides. The chemical compositions of the finegrained argillites are related to the provenance of the sediments, to the syndepositional chemical environments of deposition and to post-depositional (diagenetic) and hydrothermalmetamorphic processes ( $c f$. Lentz, 1996). Lithogeochemical profiles of Al, Ti, Zr and Y allow us to clearly distinguish these rocks from the associated intrusive lithofacies (Fig. 3). The correlation matrix based on samples from drill core KA22b permit us to identify elemental covariations attributable to the main hydrothermal alteration event. Some pairs of elements exhibit strong correlations, testifying of their strong (positive or negative) covariations as a result of alteration processes (for example: $R_{\mathrm{Nb}-\mathrm{Se}}=-0.9 ; R_{\mathrm{Th}-\mathrm{Nb}}=0.96 ; R_{\mathrm{Co}-\mathrm{Se}}=0.92 ; R_{\mathrm{Cr}-}$ $\left.\mathrm{V}=0.9 ; R_{\mathrm{Cr}-\mathrm{Nb}}=0.92 ; R_{\mathrm{Zr}-\mathrm{Al}}=0.98 ; R_{\mathrm{Al}-\mathrm{Th}}=0.95, R_{\mathrm{Al}-\mathrm{V}}=0.94 ; R_{\mathrm{Al}-\mathrm{Cr}}=0.94 ; R_{\mathrm{Ti}-\mathrm{Al}}=0.98\right)$. At Koudiat Aïcha, Al, Ti, Nb, V, and $\mathrm{Cr}$ show distinctly immobile behaviours, with covariances of about 0.9 , reflecting the primary source of these elements. $\mathrm{Al}_{2} \mathrm{O}_{3}$ is particularly useful as a reference immobile element because most other original immobile trace elements remain in mica and consequently covary with $\mathrm{Al}_{2} \mathrm{O}_{3}$.

We observe close geochemical coherences between $\mathrm{Al}_{2} \mathrm{O}_{3}$ and $\mathrm{SiO}_{2}, \mathrm{TiO}_{2}, \mathrm{P}_{2} \mathrm{O}_{5}, \mathrm{Co}, \mathrm{Th}, \mathrm{Nb}$, $\mathrm{Y}$ and $\mathrm{Al}_{2} \mathrm{O}_{3}+\mathrm{Na}_{2} \mathrm{O}+\mathrm{K}_{2} \mathrm{O}$ (Fig. 4), indicating a pelagic-terrigenous sources for the micas ( $c f$. [Bonatti et al., 1972] and [Lentz, 1996]). However, the covariation is less clear between $\mathrm{Al}_{2} \mathrm{O}_{3}$ and $\mathrm{MgO}, \mathrm{Fe}_{2} \mathrm{O}_{3}$ and trace elements, probably due to subsequent alterations. The alteration index diagram $\mathrm{Al}_{2} \mathrm{O}_{3} / \mathrm{Al}_{2} \mathrm{O}_{3}+\mathrm{Na}_{2} \mathrm{O}+\mathrm{K}_{2} \mathrm{O}$ versus $\mathrm{Na}_{2} \mathrm{O}$ (not illustrated) suggests a highly pelagic origin for the micas, with $\mathrm{Na}_{2} \mathrm{O}>0.65$ (Taylor and McLennan, 1985). The Boström diagram Al/Al $+\mathrm{Fe}+\mathrm{Mn}$ versus Fe/Ti (Fig. 5a; Boström, 1973) and the ternary diagram Al$\mathrm{Fe}-\mathrm{Mn}$ (Fig. 5b; Boström, 1973) also suggest that a terrigenous-pelagic detritus (reflected in high $\mathrm{Al}_{2} \mathrm{O}_{3}$ contents) is combined with a minor hydrothermal component (high $\mathrm{Fe}$ and $\mathrm{Mn}$ ).

In addition to using the above approaches to characterize the chemostratigraphy of the Koudiat Aïcha sedimentary rocks, we have also tested the log (ratio) method or Al normalization at constant values or as fractions (e.g., Ti/Al, Zr/Al, Y/Al...) ([Kerrich, 1982] and [Bernier and MacLean, 1993]) to outline differences between the footwall and the immediate hanging wall sediments. Fig. 6a shows that the argillites are quite similar and probably share a common source, and that $\mathrm{Al}, \mathrm{Zr}, \mathrm{Ti}, \mathrm{Cr}$ and $\mathrm{V}$ are immobile elements. This conclusion is confirmed by the argillite REE paths for footwall and hanging wall samples (Fig. $8 a)$.

To ascertain the chemical composition and magmatic affinity of the interpreted mafic and felsic magmatic rocks, we have used the petrography and chemical data of least-altered rocks as reference samples (Fig. $8 \mathrm{~b}$ and c). The least-altered mafic sills in the footwall and hanging wall are basaltic in composition (gabbro), with $\mathrm{SiO}_{2}$ clustering around 50 wt. $\%$ and $\mathrm{Na}_{2} \mathrm{O}+\mathrm{K}_{2} \mathrm{O}$ around 2.65 wt.\%. Based on REE profiles and $\mathrm{Zr}$ versus $\mathrm{Y}$ diagrams (Fig. 7 and Fig. 8b), the gabbros have a tholeiitic affinity, similarly to most plutonic sequences in the Central Jebilet domain and the Guemassa massif (Aarab, 1995). 
Our felsic volcanic flows vary in composition from rhyodacite to dacite (Fig. 7a), with $\mathrm{SiO}_{2}$ between 56 and 67 wt.\% (Table 2) and $\mathrm{Na}_{2} \mathrm{O}+\mathrm{K}_{2} \mathrm{O}$ varying from 3.12 to $5.26 \mathrm{wt} . \%$. These rocks appear to be cogenetic with the gabbros, as shown from the log (ratio) analyses (Fig. $6 \mathrm{~b})$ and REE profiles (Fig. 8c). The normalized REE diagram $\left(\mathrm{Ce}_{N} / \mathrm{Yb}_{\mathrm{N}}>4\right)$ (Fig. 8c) indicate clearly their tholeiitic magmatic affinities.

\section{Hydrothermal alteration}

\subsection{Petrographic and normative signatures}

All of the rocks associated with the deposit are altered to a greater or lesser extent. The sulphide-bearing argillites display clear differences between the footwall and hanging wall in terms of modal sericite, chlorite, quartz and carbonates. These minerals also vary in proportion between proximal and distal positions relative to the mineralized zone (Fig. 9). Indeed, the footwall sequences are progressively enriched in modal chlorite and are depleted in sericite near and within the sulphide zones (Fig. 9 and Fig. 10). Chloritization is sparsely present in the hanging wall as much as 40-60 m above the sulphide mineralization, and chlorite varies from olive-green outside the sulphide zones to bluish within the sulphide horizons. Silica is enriched locally as quartz veins and as centimetric layers of chert (Fig. 10d). Sericite rather than chlorite is widespread in the hanging wall as a $30 \mathrm{~m}$-wide halo associated with lesser chlorite contents. Sericitization is noticeable by the progressive change of colour of the argillites from black to grey to silver-grey, typically with a noticeable softening of the rock. The sericitization of the hanging wall is typically associated with restricted disseminations of pyrrhotite, commonly seen as nodules stretched parallel to the $\mathrm{S}_{1}$ foliation.

Mineralogical changes across the Koudiat Aïcha deposit may also be detected in the calculation of normative mineral abundances using whole-rock chemical compositions (Piché and Jebrak, 2004). The hydrothermal alterations around volcanogenic deposits are largely formed under temperatures of $200-400{ }^{\circ} \mathrm{C}$ and moderate (sub-seafloor) pressures, producing a mineralogical alteration assemblage consisting mainly of quartz, chlorite, sericite, albite and calcite (Franklin et al., 2005). Because hydrothermal alteration minerals do not recrystallize or react readily under low-grade regional metamorphism (Barrett and MacLean, 1994), their occurrence may be preserved when calculating normative alteration mineral assemblages (sericite-quartz-albite, and sericite-chlorite-albite); this feature is evident on the ternary diagram for Koudiat Aïcha host rocks (Fig. 11). The ternary albite-muscovite-chlorite diagram allows us to differentiate between the sedimentary facies of the footwall and hanging wall. The hanging wall facies migrate towards the pole of muscovite, whereas the footwall facies trends toward chlorite-albite. This observation explains the sericitization of hanging wall rocks and the chloritization of the footwall rocks. Na in the footwall is removed from albite, and the residual $\mathrm{Al}$ and $\mathrm{Si}$ is combined with $\mathrm{Fe}, \mathrm{Mg}$, and $\mathrm{K}$ to form chlorite and sericite in the host rock as well as in their hydrothermally altered equivalents. We observe that the footwall argillites fall on the chlorite-albite line (Fig. 11) and are distinctly chloritized, whereas the hanging wall argillites associated with disseminated pyrrhotite are richer in sericite. 


\subsection{Chemical profiles}

The geochemical data for samples from drill core KA22b were examined to identify geochemical changes associated with sulphide mineralization (i.e., related to hydrothermal alteration). The geochemical profiles indicate that $\mathrm{SiO}_{2}, \mathrm{TiO}_{2}, \mathrm{MnO}, \mathrm{Fe}_{2} \mathrm{O}_{3}, \mathrm{Al}_{2} \mathrm{O}_{3}, \mathrm{MgO}, \mathrm{K}_{2} \mathrm{O}$, $\mathrm{P}_{2} \mathrm{O}_{5}$ and $\mathrm{CaO}$ were mobilized relative to each other during hydrothermal water-rock interactions. $\mathrm{FeO}$ and $\mathrm{MgO}$ may be grouped $(\mathrm{FeO}+\mathrm{MgO})$ as a principal component of chlorite, while $\mathrm{CaO}$ and $\mathrm{Na}_{2} \mathrm{O}$ are grouped $\left(\mathrm{CaO}+\mathrm{Na}_{2} \mathrm{O}\right)$ as a single component of feldspars. In the same way, $\mathrm{K}_{2} \mathrm{O}$ can be considered as a principal component of white mica (sericite), while $\mathrm{Al}_{2} \mathrm{O}_{3}$ is the only component common to all feldspars and micas.

The relative intensity of alteration around the sulphide lenses can be quantified by several alteration indices (Fig. 12) based on cationic ratios for chlorite and sericite indices (Kishida and Kerrich, 1987). As observed around other VMS deposits, the ( $\mathrm{Fe}+\mathrm{Mg}) / \mathrm{Al}$ index may be used to identify the addition of chlorite ([Riverin and Hodgson, 1980] and [Galley, 1995]), whereas the $\mathrm{Na} / \mathrm{Al}$ index (Spitz and Darling, 1978) may indicate the behaviour of feldspars during hydrothermal alteration. At Koudiat Aïcha, $(\mathrm{Fe}+\mathrm{Mg}) / \mathrm{Al}$ increases from the distal to proximal footwall (Fig. 12), dissimilar to the $3 \mathrm{~K} / \mathrm{Al}$ index used to recognize feldspar hydrolysis.

\subsection{Mineral compositions}

The compositions of chlorite and sericite, from least-altered to highly altered argillites, was determined using an electron microprobe to detect possible compositional differences in these minerals in samples collected across the stratigraphic section, from footwall to hanging wall.

Chlorite compositions were determined for seven samples (45 point analyses) taken along samples from diamond drill core KA25 which transects the footwall and hanging wall rocks (Table 3a). Chlorite interbedded with sulphide bodies is dark and Mg-rich ( $>20 \mathrm{wt} . \% \mathrm{MgO}$, $<15$ wt.\% FeO), equivalent to a sheridanite-ripidolite composition (Fig. 13). In the immediately underlying footwall, the chlorite is Fe-rich ripidolite ( $<15 \mathrm{wt} . \% \mathrm{MgO},>15 \mathrm{wt} . \%$ $\mathrm{FeO}$; Fig. 13). The $\mathrm{Fe}_{\text {total }} /\left(\mathrm{Fe}_{\text {total }}+\mathrm{Mg}\right)(\mathrm{FM})$ ratio extends from 0.28 to 0.47 , with the lower values corresponding closely to the sulphide zones and their proximal footwall halos, suggesting a strong Mg metasomatism during the hydrothermal emplacement of sulphides.

The chlorite composition is commonly used as a hydrothermal geothermometer ([Cathelineau and Nieva, 1985], [Kranidiotis and MacLean, 1987] and [Slack and Coad, 1989]), based on the tetrahedral aluminum $\left(\mathrm{Al}^{\mathrm{IV}}\right)$ concentration of chlorites, for which $T=106 \mathrm{Al}^{\mathrm{IV}}+18$ (Slack and Coad, 1989). The application of this equation requires corrections for tetrahedral Al, by adding $0.7 \mathrm{FM}$ for those chlorites that have not reached the $\mathrm{Al}^{\mathrm{IV}}$ saturation limit (Table 4). This chlorite geothermometer suggests temperatures between 308 and $330{ }^{\circ} \mathrm{C}$ for chlorites interbedded with sulphides and in the immediately underlying footwall. Distal chlorites, formed before and after the sulphides, have temperatures of formation around $250{ }^{\circ} \mathrm{C}$.

White mica (sericite) is the second most-common phyllosilicate in the host rocks. It is widespread in least-altered as well as more severely altered rocks, and it is especially abundant in the hanging wall. Its chemical composition has been determined for 10 samples collected along the diamond drill core KA25 (72 analyses) from the footwall to the hanging wall (Table 3b). Projected on a Velde (1977) diagram, the analyses show that most of the white micas are pure muscovite (Fig. 14a). Chemical analyses show traces of Ti, insignificant 
amounts of $\mathrm{Cr}, \mathrm{V}, \mathrm{Mn}$ and $\mathrm{Zn}$, and up to $4.5 \% \mathrm{H}_{2} \mathrm{O}$ (calculated). $\mathrm{Fe}$ and $\mathrm{Mg}$ increase toward the sulphide zones, whereas $\mathrm{K}$ decreases within sulphide zones and in the footwall (Fig. 14b). $\mathrm{Fe}$ and $\mathrm{Mg}$ in the hanging wall decrease away from the sulphide zones, reflecting a chemical change of white micas toward biotite compositions as a result of metamorphism. Biotite is sparsely observed within the argillites, but where found, it typically replaces sericite.

\subsection{Mass changes}

Mass-balance calculations have commonly been used in the analysis of hydrothermal systems in volcanogenic-associated massive sulphide settings to detect alteration effects (MacLean and Barrett, 1993). At Koudiat Aïcha, such calculations were used to identify mineralogical changes and alteration indices. The isocone method (Grant, 1986) has been applied to argillites to express the gain (positive) or loss (negative) of elements in the vicinity of the sulphide horizon. Our sampling contrasts the footwall argillites (altered rocks) with their distal equivalents (least-altered rocks) along drill core KA22b (Fig. 15). In these diagrams, the best-fit isocone is drawn for the elements considered to be immobile during the alteration event. All of the elements located above the isocone are considered enriched (i.e., have experienced gains) and those elements located below are depleted (have experienced losses).

Using superposed anomalies of the major mobile elements, it can be seen that hydrothermal alteration produced a large chemical halo in the footwall (about 40-60 m thick). $\mathrm{Fe}_{2} \mathrm{O}_{3}, \mathrm{MgO}$ and $\mathrm{MnO}$ (seen as chloritization) have been significantly enriched in the footwall, whereas $\mathrm{Na}_{2} \mathrm{O}, \mathrm{CaO}$ and $\mathrm{K}_{2} \mathrm{O}$ were lost (reflecting the breakdown of feldspars and sericite). $\mathrm{SiO}_{2}$ is substantially enriched within the alteration halo (Fig. 15 and Fig. 16). The hanging wall sequence, on the other hand, shows enrichments in $\mathrm{K}_{2} \mathrm{O}, \mathrm{MgO}$, and $\mathrm{Fe}_{2} \mathrm{O}_{3}$, and losses of $\mathrm{CaO}$ and $\mathrm{Na}_{2} \mathrm{O}$ near the mineralized horizon (Fig. 16), corresponding to seritization enrichment, in contrast to the chloritization seen at the level of the mineralized footwall.

\subsection{Oxygen and hydrogen isotopes}

The oxygen and hydrogen isotope compositions are sparsely available from previous studies of sulphide deposits in the Central Domain and Guemassa massif (Draa Sfar, Kettara, Hajar). Mineral-pair oxygen isotope compositions would provide the best estimates of ore fluid temperatures, given that fluid inclusion analyses are lacking for these Hercynian deposits. Those minerals that have been analyzed are quartz, hornblende, sericite, chlorite, albite and whole rocks studied in the current research. The analyzed samples were collected from outcrops and drill core KA22b, and represent argillites, gabbros and the rhyodacite lithofacies (Table 5, Fig. 17a).

The $\delta^{18} \mathrm{O}$ and $\delta \mathrm{D}$ values calculated for hydrothermal fluids show narrow ranges $(+6.2 \%$ to $+12.4 \%$, and $-28 \%$ o to $-52 \%$, respectively) for all magmatic and sedimentary whole rocks; the same observation applies for mineral pairs constituting the host rocks of the footwall and hanging wall of the massive sulphide deposits (Fig. 17a).

The $\delta^{18} \mathrm{O}$ and $\delta \mathrm{D}$ data indicate that magmatic and metamorphic waters were the dominant components of the hydrothermal fluids (Fig. 17b). No significant spatial (vertical) isotopic variation has been observed across the footwall and hanging wall along the sampled profile. Indeed, the isotopic compositions of argillites are closer to those of gabbros which may 
have played a role as a heat source for the hydrothermal fluid. The temperatures of deposition calculated using mineral-pair geothermometry range from approximately $310-380{ }^{\circ} \mathrm{C}$. These results are in excellent agreement with temperatures of $300-330{ }^{\circ} \mathrm{C}$ obtained using the chlorite geothermometer on several VMS deposits (Slack and Coad, 1989). Given the similar values for argillites and gabbro, $\delta^{18} \mathrm{O}$ and $\delta \mathrm{D}$ data suggest that the hydrothermal fluid probably originated from the same magmatic reservoir as the gabbro and re-equilibrated subsequently with a metamorphic fluid which was released during the Hercynian deformation event and reacted with various lithologies of the Koudiat Aïcha deposit.

\section{Discussion and conclusions}

This study allows us to understand the primary mineralogical and geochemical environments of the Koudiat Aïcha deposit and to identify the mineralogical and geochemical signatures of the hydrothermal fluid associated with sulphide deposition. The predominance of a thick sequence of pelagic-terrigenous grey-black argillites, the widespread formation of Fe-rich chlorite, and the pyrrhotitic nature of the deposit are all indicative of a low $f \mathrm{O}_{2}$ depositional environment for the sulphide lenses ([Beauchamp et al., 1991] and [Belkabir et al., 2008]). The Koudiat Aïcha argillites were formed by sedimentation from suspended material in an anoxic basin, whereas the minor siltstones and sandstones correspond to turbidites derived from local tectonic instabilities.

The magmatic environment of Koudiat Aïcha is characterized by a predominance of gabbro sills and, less commonly, rhyodacite flows and tuffs. The gabbros with a tholeiitic affinity (both below and above mineralization) preceded metamorphism and deformation, and imply a magmatic heat source for the hydrothermal ore system (Lotfi et al., 2008). The hydrothermal envelope surrounding the deposit is asymmetric from the footwall up to the hanging wall. Even though the sulphide deposits do not exhibit a clear feeder zone (also true for the Draa Sfar deposit; Marcoux et al., 2008), the footwall is remarkably well outlined by a proximal and semi-conformable chloritic alteration halo. This footwall alteration is characterized by extensive magnesium metasomatism (Mg-chlorite) located within and adjacent to the sulphide bodies and probably outlines the zone of high temperatures associated with hydrothermal alteration (Barrett and MacLean, 1999). The enrichment of $\mathrm{FeO}+\mathrm{MgO}$ within massive sulphide mineralization is common in VMS deposits ([Riverin and Hodgson, 1980] and [Galley, 1995]) and is related to an increase of chlorite, which in turn derives from the heatinduced circulation of seawater containing magnesium. This alteration suggests high temperatures and high water/rock ratios in the discharge zone, with important leachings of $\mathrm{K}_{2} \mathrm{O}, \mathrm{Na}_{2} \mathrm{O}, \mathrm{CaO}$, a moderate loss of $\mathrm{SiO}_{2}$ and precipitation of $\mathrm{FeO}_{\text {total }}, \mathrm{MgO}$ and $\mathrm{MnO}$ (Fig. 15 and Fig. 16). In the hanging wall, argillites are less chloritized and enriched in sericite (Krich) and are also progressively enriched upward in $\mathrm{Ca}$, as seen by a late calcite filling of narrow veins (Fig. 16). The sericitization of the hanging wall may have resulted from a temperature decrease during the basin filling (see Lentz, 1994) and/or the precipitation of hydrothermal and detrital suspension materials (see Belkabir et al., 2008). Indeed, experimental data show that the mobility of potassium is chiefly related to temperatures above $150^{\circ} \mathrm{C}$, and is less apparent at low temperature (Seyfried and Bischoff, 1979). The mobility of $\mathrm{Na}$ is, however, largely dependent on the water/rock ratio. For ratios $>10, \mathrm{Na}$ is leached from the rock and is enriched in the hydrothermal solution (Seyfried and Bischoff, 1977), whereas for ratios $<5, \mathrm{Na}$ is fixed and excluded from the hydrothermal (sea) water (Mottl and Holland, 1978). In the literature, calcite precipitation is attributed to cooling temperatures, and the observed progressive carbonate enrichment in the distal hanging wall rocks of many sulphide-bearing basins results in part from cooling $\left(T<350^{\circ} \mathrm{C}\right)$ of the ore fluid (Fournier, 
1985). Taking into account these data, the Koudiat Aïcha deposit shows $T>150{ }^{\circ} \mathrm{C}$ at the footwall and water/rock ratios $>10$ associated with the development of massive chlorite. In the hanging wall, $T<150{ }^{\circ} \mathrm{C}$ and $\mathrm{W} / \mathrm{R}$ ratios $<5$ account for the development of sericite and the local deposition of calcite as veins and small calcite layers. The asymmetry of the alteration envelope from footwall to hanging wall may be due to closing stages in the flow of hydrothermal fluid system after the deposition of the Koudiat Aïcha sulphide mineralization.

From mass balance calculations, the footwall exhibits an almost complete loss of $\mathrm{Na}, \mathrm{Ca}$ and $\mathrm{K}$, and a minor loss in silica. The hydrothermal fluids (magmatic and possibly meteoric) circulating through the volcano-sedimentary sequences would have been enriched in $\mathrm{Fe}, \mathrm{Mg}$ and associated base metals leached from the predominantly sedimentary footwall. These fluids precipitated chlorite and sulphides, with sulphur derived from the reduction of biogenic marine sulphates (Lotfi et al., 2008).

The study of the Koudiat Aïcha deposit and its surrounding geological setting (this study and Lotfi et al., 2008) allow us to compare Koudiat Aïcha with other VMS deposits of the Central Jebilet and Guemassa massifs ([Bordonaro et al., 1979], [Bordonaro, 1983], [Belkabir et al., 2008] and [Marcoux et al., 2008]) and to understand the geological spectrum of Hercynian deposits in Morocco. Koudiat Aïcha is a polymetallic VMS deposit representing a particular geological environment distinct from others in the rest of the Central Jebilet and Guemassa massifs (for example, Hajar, Draa Sfar, and Kettara). It lacks a thick felsic volcanic component and it is certainly genetically related to mafic intrusive rocks.

In Lotfi et al. (2008), the model of Besshi-type mineralization (e.g., Besshi Shikoku, Japan; Windy Graggy, northerwestern British Columbia, Canada; Ducktown district USA; Slack, 1993) has been proposed for the Koudiat Aïcha deposit. This genetic model is supported by the presence of mafic rather felsic magmatism, by dominant siliciclastic sedimentary rocks, by the elongated and tabular form of the massive ore zone (deformed), by the ore mineralogy (chalcopyrite-pyrite-pyrrhotite and lesser sphalerite and galena), and by the absence of a feeder zone (Franklin et al., 1981).

In this work, we have investigated the mineralogy and geochemistry of the Koudiat Aïcha deposit which represents a particular VMS deposit in the Hercynian volcano-sedimentary terrain. We have explained the chemostratigraphic setting of the ore zone and the probable similarity of the Koudiat Aïcha with the rare Besshi-type mineralization.

\section{Acknowledgements}

This paper is part of the doctoral thesis of the first author carried out at the Cadi Ayyad University, Marrakech. We especially thank l'Agence Universitaire pour la Francophonie, le Programme thématique d'appui à la recherche scientifique of the Ministry of Education, Morocco (PROTARS P23-05), l'Institut des Sciences de la Terre d'Orléans, le Bureau de Recherches Géologiques et Minières, l'École Polytechnique de Montréal, and the Natural Science and Engineering Research Council of Canada for financial support and for the use of their facilities. We are also indebted to the Reminex Exploration Company for access to their field area, drill cores and exploration data. Constructive and very thorough reviews by $\mathrm{S}$. Muhongo and $\mathrm{M}$. Lompo and the journal editor are gratefully acknowledged.

\section{References}


Aarab, 1995 Aarab, El., 1995. Genèse et différentiation d'un magma tholeitique en domaine extensif intracontinental: l'exemple du magmatisme pre-orogenique des Jebilet (Maroc Hercynien). Thèse d'état, Université Cadi Ayyad, Maroc, 235 p.

Barrett and MacLean, 1999 T.J. Barrett and W.H. MacLean, Volcanic sequences, lithogeochemistry, and hydrothermal alteration in some bimodal volcanic-associated massive sulfide systems, Reviews in Economic Geology 8 (1999), pp. 101-131.

Barrett and MacLean, 1994 T.J. Barrett and W.H. MacLean, Mass changes in hydrothermal alteration zones associated with VMS deposits of the Noranda area, Exploration and Mining Geology 3 (1994), pp. 131-160.

Beauchamp et al., 1991 J. Beauchamp, A. Izart and A. Piqué, Les bassins d'avant-pays de la chaîne hercynienne au Carbonifère inférieur, Canadian Journal of Earth Sciences 28 (1991), pp. 2024-2041.

Beauchamp, 1984 J. Beauchamp, Le Carbonifère inférieur des Jebilet et de l'Atlas de Marrakech (Maroc): migration et comblement d'un bassin marin, Bulletin Société Géologique de France 7 XXVI (6) (1984), pp. 1025-1032.

Belkabir et al., 2008 A. Belkabir, H. Gibson, E. Marcoux, D. Lentz and S. Rziki, Geology and wall-rock alteration at the Hercynian Draa $\mathrm{Sfar} \mathrm{Zn}-\mathrm{Pb}-\mathrm{Cu}$ deposit, Morocco, Ore Geology Reviews 33 (3-4) (2008), pp. 280-306.

Bernier and MacLean, 1993 L.R. Bernier and W.H. MacLean, Lithogeochemistry of a metamorphosed VMS alteration zone at Montauban, Grenville Province, Quebec, Exploration and Mining Geology 2 (1993), pp. 367-386.

Bonatti et al., 1972 E. Bonatti, T. Kraemer and H. Rydell, Classification and genesis of submarine iron-manganese deposits. In: D. Horn, Editor, Ferromanganese Deposits from the Ocean Floor, Symposium, Columbia Univ. (1972), pp. 149-165.

Bordonaro, 1983 Bordonaro, M., 1983. Tectonique et pétrographie du district à pyrrhotite de Kettara (Paléozoïque des Jebilet, Maroc). Thèse de 3ème cycle, Université Louis Pasteur, Strasbourg, $132 \mathrm{p}$.

Bordonaro et al., 1979 M. Bordonaro, J.L. Gaillet and A. Michard, Le géosynclinal carbonifère sud-mésétien dans les Jebilet (Maroc); une corrélation avec la province pyriteuse du sud de l'Espagne, Compte Rendus Académie Sciences Paris 288-D (1979), pp. 1371-1374.

Boström, $1973 \mathrm{~K}$. Boström, The origin and fate of ferromanganoan active ridge sediments, Stockholm Contributions in Geology 27 (1973), pp. 147-243.

Cathelineau and Nieva, 1985 M. Cathelineau and D. Nieva, A chlorite solid solution geothermometer: the Los Azufres (Mexico) geothermal system, Contributions to Mineralogy and Petrology 91 (1985), pp. 235-244.

Epstein and Taylor, 1970 S. Epstein and H.P. Taylor Jr., ${ }^{18} \mathrm{O} /{ }^{16} \mathrm{O},{ }^{30} \mathrm{Si} /{ }^{28} \mathrm{Si}, \mathrm{D} / \mathrm{H}$, and ${ }^{13} \mathrm{C} /{ }^{12} \mathrm{C}$ studies of lunar rocks and minerals, Science 167 (1970), pp. 533-535. 
Fournier, 1985 Fournier, R.O., 1985. The behavior of silica in hydrothermal solutions. In: Berger, B.R., Bethke, P.M. (Eds.), Geology and Geochemistry of Epithermal Systems. Reviews in Economic Geology, vol. 2, pp. 45-61.

Franklin et al., 2005 J.M. Franklin, H.L. Gibson, I.R. Jonasson and A.G. Galley, Volcanogenic massive sulphide deposits, Economic Geology (2005), pp. 523-560 (100th anniversary volume).

Franklin et al., 1981 Franklin, J.M., Sangster, D.M., Lydon, J.W., 1981, Volcanic-associated massive sulfide deposits. In: Skinner, B.J. (Ed.), Economic Geology, pp. 485-626 (75th anniversary volume).

Galley, 1995 A.G. Galley, Target vectoring using lithogeochemistry: applications to the exploration for volcanic-hosted massive sulphide deposits, Canadian Institute of Mining and Metallurgy Bulletin 88 (990) (1995), pp. 15-27.

Grant, 1986 J.A. Grant, The isocon diagram: a simple solution to Gresens' equation for metasomatic alteration, Economic Geology 80 (1986), pp. 1976-1982.

Hedenquist and Lowenstern, 1994 J.W. Hedenquist and J.B. Lowenstern, The role of magmas in the formation of hydrothermal ore deposits, Nature 370 (1994), pp. 519-527

Hey, 1954 M.H. Hey, A new review of the chlorites, Mineralogical Magazine 30 (1954), pp. 277-292.

Huvellin, 1977 Huvellin, P., 1977. Etude géologique et gîtologique du Massif hercynien des Jebilet (Maroc occidental). Notes Mém Serv Géol Maroc 232bis, 307 p.

Jenner, 1996 Jenner, G.A., 1996. Trace element geochemistry of igneous rocks; geochemical nomenclature and analytical geochemistry. In: Wyman, D.A. (Ed.), Trace Element Geochemistry of Volcanic Rocks: Applications for Massive Sulfide Exploration. Short Course Notes, vol. 12. Geological Association of Canada, pp. 51-77.

Kerrich, 1982 R. Kerrich, Geochemistry of gold deposits in the Abitibi greenstone belt, Canadian Institute of Mining and Metallurgy 27 (1982), p. 75 (Special Volume).

Kishida and Kerrich, 1987 A. Kishida and R. Kerrich, Hydrothermal alteration zoning and gold concentration at the Kerr-Addison Archean lode gold deposit, Kirkland Lake, Ontario, Economic Geology 5 (82) (1987), pp. 649-687.

Kranidiotis and MacLean, 1987 P. Kranidiotis and W.H. MacLean, Systematics of chlorite alteration at the Phelps Dodge massive sulfide deposit, Quebec, Economic Geology 82 (1987), pp. 1898-1911.

Lentz, 1996 Lentz, D.R., 1996. Trace-element systematics of felsic volcanic rocks associated with massive-sulfide deposits in the Bathurst Mining Camp: petrogenetic, tectonic and chemostratigraphic implications for VMS deposits. In: Wyman, D.A. (Ed.), Trace Element Geochemistry of Volcanic Rocks: Applications for Massive Sulfide Exploration. Geological Association of Canada. Short Course Notes, vol. 12, pp. 359-402. 
Lentz, 1994 D. Lentz, Multiple episodes of brecciation and mineralization associated with an epizonal granite porphyry, True Hill, southwestern New Brunswick, Exploration and Mining Geology 3 (1994), pp. 9-16.

Lesher et al., 1986 C.M. Lesher, A.M. Goodwin, I.H. Campbell and M.P. Gorton, Trace element geochemistry of ore-associated and barren, felsic metavolcanic rocks in the Superior Province, Canada, Canadian Journal of Earth Sciences 23 (1986), pp. 222-237.

Lotfi et al., 2008 F. Lotfi, A. Belkabir, A.C. Brown, E. Marcoux, S. Brunet and L. Maacha, Geology and mineralogy of the Hercynian Koudiat Aïcha polymetallic ( $\mathrm{Zn}, \mathrm{Pb}, \mathrm{Cu}$ ) massive sulfide deposit, Central Jebilet, Morocco, Exploration and Mining Geology 17 (3-4) (2008), pp. 145-162.

Ludden et al., 1982 J.N. Ludden, L. Gélinas and P. Trudel, Archean metavolcanics from the Rouyn-Noranda district, Abitibi Greenstone belt, Québec. 2. Mobility of trace elements and petrogenetic constraints, Canadian Journal of Earth Sciences 19 (1982), pp. 2276-2287.

MacLean and Barrett, 1993 W.H. MacLean and T.J. Barrett, Lithogeochemical techniques using immobile elements, Journal of Geochemical Exploration 48 (1993), pp. 109-133.

MacLean and Kranidiotis, 1987 W.H. MacLean and P. Kranidiotis, Immobile elements as monitors of mass transfer in hydrothermal alteration: Phelps Dodge massive sulfide deposit, Matagami, Quebec, Economic Geology 82 (1987), pp. 951-962.

Marcoux et al., 2008 E. Marcoux, A. Belkabir, H. Gibson and D. Lentz, The Draa Sfar ore deposit (Jebilet, Morocco): an example of pyrrhotite dominant-polymetallic VHMS in Hercynian terranes, Ore Geology 33 (3-4) (2008), pp. 304-328.

Mottl and Holland, 1978 M.J. Mottl and H.D. Holland, Chemical exchange during hydrothermal alteration of basalt by seawater, I. Experimental results for major and minor components of seawater, Geochimica et Cosmochimica Acta 42 (1978), pp. 1103-1115.

Piché and Jebrak, 2004 M. Piché and M. Jebrak, Normative minerals and alteration indices developed for mineral exploration, Journal of Geochemical Exploration 82 (2004), pp. 59-77.

Riverin and Hodgson, 1980 G. Riverin and J. Hodgson, Wall-rock alteration at the Millenbach $\mathrm{Cu}-\mathrm{Zn}$ mine, Noranda, Quebec, Economic Geology 75 (1980), pp. 424-444.

Seyfried and Bischoff, 1979 W.E. Seyfried Jr. and J.L. Bischoff, Low temperature basaltalteration by sea water: an experimental study at $70^{\circ} \mathrm{C}$ and $150{ }^{\circ} \mathrm{C}$, Geochimica et Cosmochimica Acta 43 (1979), pp. 1937-1948.

Seyfried and Bischoff, 1977 W.E. Seyfried Jr. and J.L. Bischoff, Hydrothermal transport of heavy metals by seawater. The role of seawater/basalt ratio, Earth and Planetary Letters 34 (1977), pp. 71-77.

Slack, 1993 J.F. Slack, Descriptive and grade-tonnage models for Besshi-type massive sulfide deposits. In: R.V. Kirkham, W.D. Sinclair, R.I. Thorpe and J.M. Duke, Editors, Mineral Deposit Modeling, Geological Association of Canada (1993), pp. 343-372 (Special Paper 40). 
Slack and Coad, 1989 J.F. Slack and P.R. Coad, Multiple hydrothermal and metamorphic events in the Kidd Creek volcanogenic massive sulfide deposit, Timmins, Ontario: evidence from tourmalines and chlorites, Canadian Journal of Earth Sciences 26 (1989), pp. 694-715.

Spitz and Darling, 1978 G. Spitz and R. Darling, Major and minor element lithogeochemical anomalies surrounding the Louvem copper deposit, Val d'Or, Québec, Canadian Journal of Earth Sciences 15 (7) (1978), pp. 1161-1169.

Sun and McDonough, 1989 S.S. Sun and W.F. McDonough, Chemical and isotopic systematics of oceanic basalts: implications for mantle composition and processes. In: A.D. Saunders and M.J. Norry, Editors, Magmatism in the Ocean Basins, Geological Society of London (1989), pp. 313-345 (Special Publication 42).

Taylor and McLennan, 1985 St.R. Taylor and S.M. McLennan, The Continental Crust: Its Composition and Evolution, Blackwell Scientific Publications, Oxford (1985) 312 p.

Velde, 1977 B. Velde, Clays and Clay Minerals as Natural and Synthetic Systems. Development in Sedimentology, Elsevier Scientific Publishing Co., Amsterdam, Oxford, New York (1977).

Winchester and Floyd, 1977 J.A. Winchester and P.A. Floyd, Geochemical discrimination of different magma series and their differentiation products using immobile elements, Chemical Geology 20 (1977), pp. 325-343. 
Figures and Tables
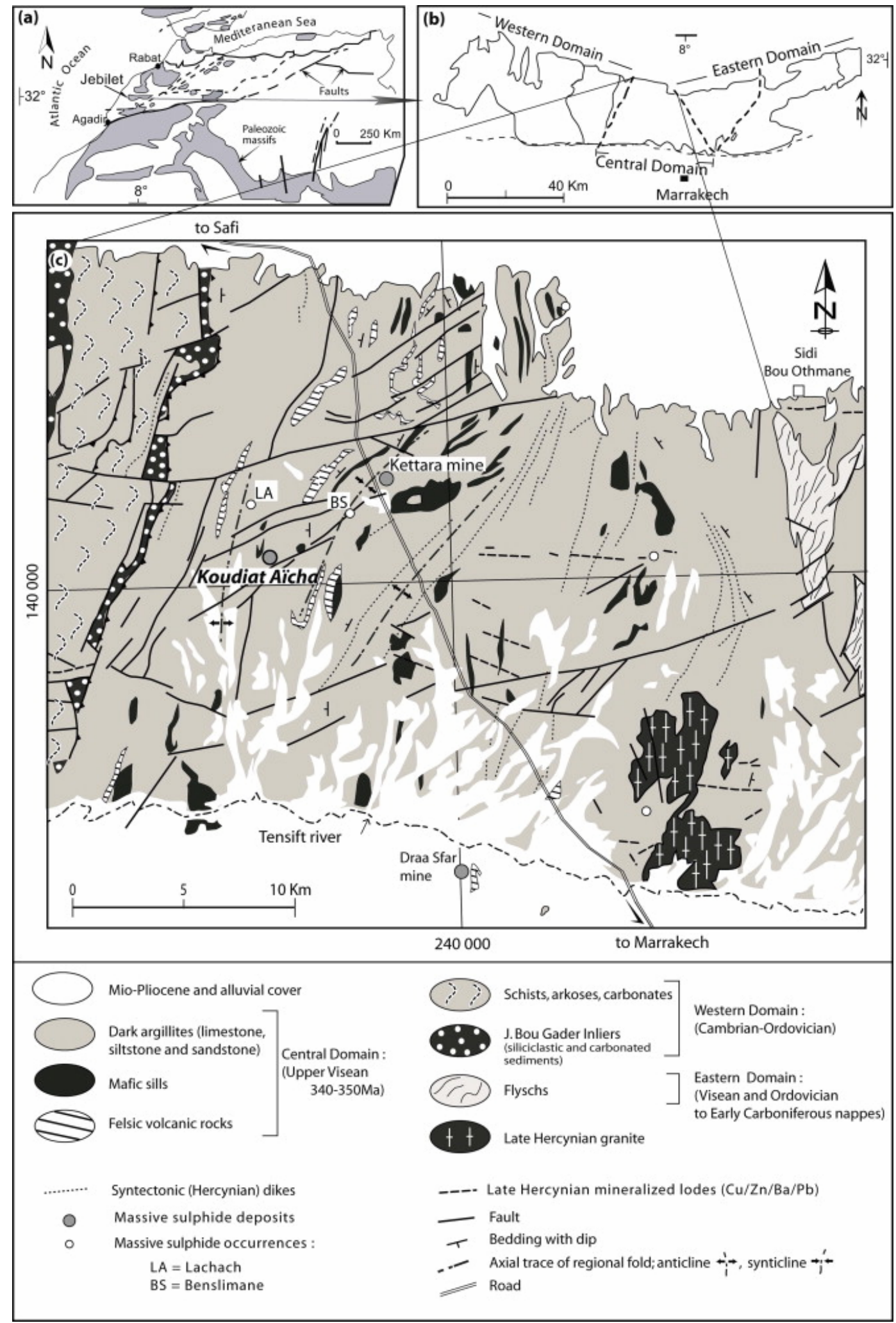

Fig. 1. : (a) The Jebilet massif in the framework of the Paleozoic outcrops of North Africa (in grey). (b) Scheme of the Jebilet massifs showing its subdivision in three domains. (c) General geological map of the Central Jebilet massif showing the location of the principal massive sulphide deposits (modified from Huvellin, 1977). 
Table 1. Summary of petrographic features of the principal lithofacies at the Koudiat Aïcha deposit.

\begin{tabular}{|l|l|l|}
\hline Lithofacies & Description & Mineralogy \\
\hline Argillites & $\begin{array}{l}\text { Black-grey, fine-grained, weakly bedded and well } \\
\text { foliated, with slaty cleavage }\end{array}$ & $\begin{array}{l}\text { qtz }(10-20 \%), \text { ser-chl and } \pm \text { bt. } \\
(50-70 \%), \text { ep, traces of ru, ox } \\
\text { and po }\end{array}$ \\
\hline Sandstone/Siltstone & $\begin{array}{l}\text { Competent layers }(0.5-1 \text { m thick), beige, fine to } \\
\text { medium grained, boudinaged }\end{array}$ & $\begin{array}{l}\text { qtz (50-95\%), ser-chl and } \pm \text { bt } \\
(10-30 \%), \text { fd (tr. })\end{array}$ \\
\hline $\begin{array}{l}\text { Carbonaceous } \\
\text { sandstones }\end{array}$ & $\begin{array}{l}\text { Discontinuous band }(0.2-1 \text { m thick), at distal HW, } \\
\text { well foliated, calcite as transposed veinules }\end{array}$ & $\begin{array}{l}\text { qtz (30-35\%), act }(10-25 \%), \text { cal } \\
(30-40 \%)\end{array}$ \\
\hline Gabbros & $\begin{array}{l}\text { Massive, doleritic border and ophitic center, dark } \\
\text { green sills with feldspar aggregates and feldspar } \\
\text { phenocrysts }\end{array}$ & $\begin{array}{l}\text { alb (40-50\%), amp-act (35- } \\
45 \%), \text { ser-chl-ilm, }(10-15 \%)\end{array}$ \\
\hline Rhyodacite & $\begin{array}{l}\text { Massive to sub-massive, grey-green, medium } \\
\text { grained with albite and quartz phenocrysts in } \\
\text { quartz-feldspar matrix }\end{array}$ & $\begin{array}{l}\text { alb (10-30\%), qtz (5-10\%), qtz- } \\
\text { fd matrix (50-60\%) }\end{array}$ \\
\hline
\end{tabular}

Note $: \mathrm{qtz}=$ quartz, $\mathrm{ser}=$ sericite, $\mathrm{chl}=$ chlorite, $\mathrm{bt}=$ biotite, $\mathrm{ep}=$ epidote, $\mathrm{ru}=$ rutile, $\mathrm{ox}=$ oxides, $\mathrm{po}=$ pyrrhotite, $\mathrm{fd}=$ feldspar, $\mathrm{cal}=$ calcite, $\mathrm{ilm}=$ ilmenite .

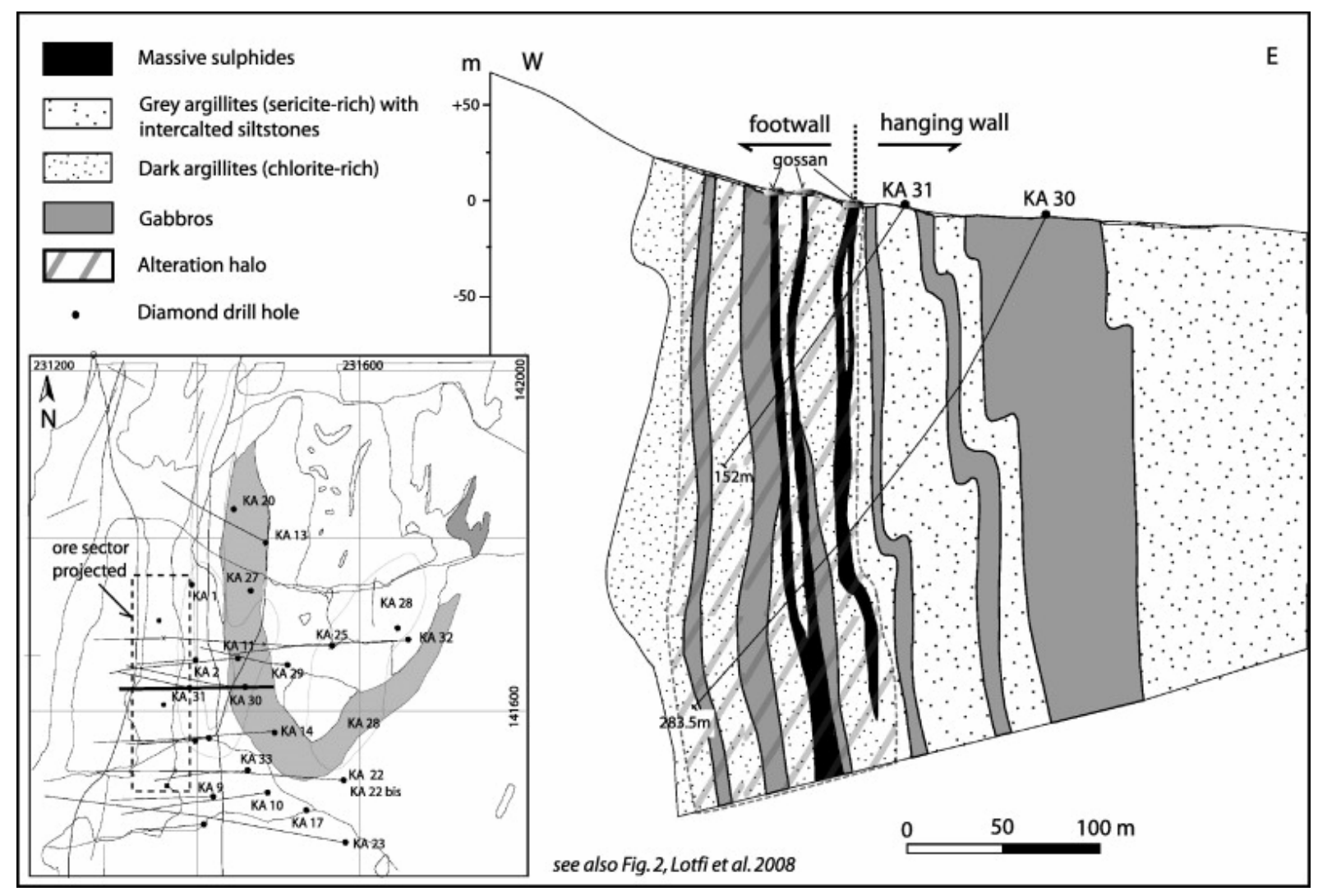

Fig. 2. : Geologic cross-section of the Koudiat Aïcha deposit showing diamond drill hole (KA) coverage. 
Table 2. Chemical analyses for Koudiat Aïcha host rocks.

\begin{tabular}{|c|c|c|c|c|c|c|}
\hline & $\begin{array}{l}\text { Gabbro } \\
\text { KA22b }\end{array}$ & $\begin{array}{l}\text { Gabbro } \\
\text { KA22b }\end{array}$ & Gabbro & Rhyodacite & $\begin{array}{l}\text { Argilites } \\
\text { KA22b }\end{array}$ & $\begin{array}{l}\text { Argillites } \\
\text { KA22b }\end{array}$ \\
\hline Sample & HW & FW & Outcrop & Outcrop & HW & FW \\
\hline Number & 3 & 8 & 6 & 3 & 9 & 14 \\
\hline $\begin{array}{l}\mathrm{SiO}_{2} \\
\text { (wt.\%) }\end{array}$ & $48-49.33$ & $47.19-48.8$ & $\begin{array}{l}47.77- \\
48.84\end{array}$ & $56-67.02$ & $50.72-60.53$ & $26-71.88$ \\
\hline $\mathrm{TiO}_{2}$ & $2.18-2.4$ & $1.489-3.039$ & $\begin{array}{l}0.889- \\
2.326\end{array}$ & $\begin{array}{l}0.963- \\
1.272\end{array}$ & $0.267-1$ & $0.285-1.034$ \\
\hline $\mathrm{Al}_{2} \mathrm{O}_{3}$ & $14.04-14.95$ & $13.6-16.33$ & $\begin{array}{l}15.79- \\
17.5\end{array}$ & $\begin{array}{l}15.86- \\
17.12\end{array}$ & $4.75-20.43$ & $5.05-20.47$ \\
\hline $\mathrm{Fe}_{2} \mathrm{O}_{3}$ & $12.36-13.6$ & $11.23-14.66$ & $8.74-21.8$ & $4.73-9.28$ & $5.61-31.42$ & $5.48-28.8$ \\
\hline $\mathrm{MnO}$ & $0.25-0.31$ & $0.199-0.283$ & $\begin{array}{l}0.155- \\
0.472\end{array}$ & $\begin{array}{l}0.077- \\
0.188\end{array}$ & $0.05-0.22$ & $0.1-0.44$ \\
\hline $\mathrm{MgO}$ & $6.86-7.91$ & $6.22-8.44$ & $7.12-8.81$ & $1.66-5.06$ & $1.71-5.93$ & $1.74-14.87$ \\
\hline $\mathrm{CaO}$ & $9.49-9.96$ & $7.36-10.11$ & $\begin{array}{l}1.83- \\
11.53\end{array}$ & $2.97-6.6$ & $0.21-5.97$ & $0.11-3.73$ \\
\hline $\mathrm{Na}_{2} \mathrm{O}$ & $1.99-2.7$ & $1.59-2.95$ & $0.23-2.27$ & $2.38-5$ & $0.16-1.25$ & $0.03-4.2$ \\
\hline $\mathrm{K}_{2} \mathrm{O}$ & $0.27-0.42$ & $0.38-1.52$ & $0.13-1.13$ & $0.26-0.74$ & $0.11-4.14$ & $0.02-2.54$ \\
\hline $\mathrm{P}_{2} \mathrm{O}_{5}$ & $0.33-0.47$ & $0.108-0.363$ & $\begin{array}{l}0.078- \\
0.253\end{array}$ & 0.2070 .296 & $0.11-0.17$ & $0.05-0.19$ \\
\hline $\begin{array}{l}\mathrm{Ba} \\
(\mathrm{ppm})\end{array}$ & $101-143$ & $28-220$ & $2-361$ & $86-140$ & $8-1146$ & $0-773$ \\
\hline $\mathrm{Co}$ & $24-38$ & $33-43$ & $32-47$ & $12.0-29$ & $5-116$ & $8-165$ \\
\hline $\mathrm{Cr}$ & $310-336$ & $302-508$ & $434-593$ & $97-277$ & $88-183$ & $56-179$ \\
\hline $\mathrm{Cu}$ & $31-114$ & $22-131$ & $12-89.0$ & $3.0-9$ & $12.0-5116$ & $4-1863$ \\
\hline $\mathrm{Ni}$ & $74-111$ & $94-150$ & 95-192 & $26-69$ & $33-64$ & $29-85$ \\
\hline $\mathrm{V}$ & $304-331$ & $234-417$ & $191-343$ & $81-186$ & $40-181$ & $30-219$ \\
\hline $\mathrm{Zn}$ & $84-174$ & $60-145$ & $42-217$ & $0-71$ & $35-7666$ & $0-317$ \\
\hline $\mathrm{Ga}$ & $19.2-20.9$ & $16.5-22.1$ & $14.4-23.3$ & $16.1-23.6$ & $3.5-26.2$ & $10.2-46.6$ \\
\hline $\mathrm{Nb}$ & $5.4-6.4$ & $0.9-6.4$ & $0.6-3.9$ & $8.8-16.7$ & $3.7-18.4$ & $5-18.6$ \\
\hline $\mathrm{Pb}$ & $2.7-7.3$ & $2.3-8.2$ & $3-18.6$ & $0.3-9$ & $7-1054.5$ & $1.2-12.5$ \\
\hline $\mathrm{Rb}$ & $9.1-15.4$ & $9.7-52.5$ & $3.2-46.7$ & $11-35.1$ & $4.4-178.9$ & $0.6-63.4$ \\
\hline
\end{tabular}




\begin{tabular}{|c|c|c|c|c|c|c|}
\hline & $\begin{array}{l}\text { Gabbro } \\
\text { KA22b }\end{array}$ & $\begin{array}{l}\text { Gabbro } \\
\text { KA22b }\end{array}$ & Gabbro & Rhyodacite & $\begin{array}{l}\text { Argilites } \\
\text { KA22b }\end{array}$ & $\begin{array}{l}\text { Argillites } \\
\text { KA22b }\end{array}$ \\
\hline $\mathrm{Sr}$ & $161.1-211$ & $107.8-181.2$ & $\begin{array}{l}11.9- \\
165.2\end{array}$ & $\begin{array}{l}298.2- \\
533.5\end{array}$ & $1.7-200.5$ & $1.6-443.6$ \\
\hline Th & $2.8-3$ & $0.7-3.4$ & $0.4-1.7$ & $9-17.3$ & $3.7-15.9$ & $5.2-15.2$ \\
\hline $\mathrm{U}$ & $1.1-1.6$ & $0.5-1.2$ & $0.3-1.3$ & $2.8-5.8$ & $1.6-4.7$ & $1.1-4.5$ \\
\hline $\mathrm{Y}$ & $49.8-53.6$ & $28.2-61.9$ & $19.8-45.9$ & $49.8-61.8$ & $18-35.6$ & $7-44.9$ \\
\hline $\mathrm{Zr}$ & $204.6-232.9$ & $95.8-239.8$ & $\begin{array}{l}50.8- \\
169.9\end{array}$ & $422.4-253$ & $138.3-215.1$ & $140.5-336.1$ \\
\hline As & $2.7-2.9$ & $0-11.9$ & $0-31.1$ & $1.4-9.3$ & $0-704.4$ & $0-7.5$ \\
\hline Sn & $3.2-6.1$ & $4-14.0$ & $2.5-11.9$ & $0-7.6$ & $0.1-16$ & $1.2-16.6$ \\
\hline $\mathrm{Hf}$ & $5.7-7.1$ & $3.7-7.8$ & $3.1-6.8$ & $8-11.6$ & $0-7.7$ & $0-7.8$ \\
\hline $\mathrm{Ta}$ & $2.6-4.2$ & $0.2-5.8$ & $0.6-9$ & $1.6-2.4$ & $0-4.4$ & $1.6-12.4$ \\
\hline $\operatorname{Pr}$ & $5.16-5.19$ & $1.82-5.3$ & $1.05-3.71$ & $7.62-9.78$ & 11.9 & 11.4 \\
\hline $\mathrm{Nd}$ & $24.7-25.4$ & $10.2-26.7$ & $6.05-13.8$ & $30.8-38.5$ & 43.2 & 41 \\
\hline $\mathrm{Sm}$ & $6.95-7.13$ & $3.32-8.01$ & $2.06-5.72$ & $7.54-8.93$ & 8.26 & 8.04 \\
\hline $\mathrm{Eu}$ & $1.84-1.95$ & $1.25-2.59$ & $\begin{array}{l}0.868- \\
2.24\end{array}$ & $1.32-1.6$ & 1.34 & 1.45 \\
\hline Gd & $8.17-8.51$ & $4.17-9.76$ & $2.75-7.07$ & $8.11-9.28$ & 7.27 & 7.41 \\
\hline $\mathrm{Tb}$ & $1.55-1.62$ & $0.8-1.8$ & $0.53-1.29$ & $1.41-1.69$ & 1.21 & 1.33 \\
\hline Dy & $9.32-9.61$ & $5.18-11.2$ & $3.44-8.15$ & $8.81-9.99$ & 6.3 & 7.7 \\
\hline Ho & $1.88-1.94$ & $1.06-2.29$ & $0.71-1.71$ & $1.76-2.07$ & 1.17 & 1.52 \\
\hline $\mathrm{Er}$ & $5.8-6.08$ & $3.26-7.01$ & $2.2-5.16$ & $5.46-7.08$ & 3.68 & 4.9 \\
\hline $\mathrm{Tm}$ & $0.86-0.9$ & $0.485-1.04$ & $\begin{array}{l}0.337- \\
0.761\end{array}$ & $0.838-1.1$ & 0.565 & 0.745 \\
\hline $\mathrm{Yb}$ & $5.4-5.61$ & $3.06-6.46$ & $2.06-4.72$ & $5.2-6.84$ & 3.4 & 4.42 \\
\hline $\mathrm{Lu}$ & $0.801-0.804$ & $0.458-0.939$ & $\begin{array}{l}0.289- \\
0.689\end{array}$ & $0.731-1.02$ & 0.483 & 0.591 \\
\hline
\end{tabular}


Table 3a. Chemical compositions of chlorite within argillite of DDH KA25.

\begin{tabular}{|c|c|c|c|c|c|c|c|}
\hline & \multicolumn{7}{|c|}{ Samples } \\
\hline & K254 & K258 & KA25-9 & KA25-10 & KA25-11 & KA25-m & KA25-14 \\
\hline Distance (m) & 336.9 & 368.5 & 396.3 & 397.05 & 398 & 421.45 & 427.15 \\
\hline Number & 6 & 4 & 5 & 5 & 4 & 20 & 1 \\
\hline $\mathrm{SiO}_{2}$ & 0.258 & 0.297 & 0.249 & 0.258 & 0.273 & 0.255 & 0.263 \\
\hline $\mathrm{FeO}$ & 0.197 & 0.219 & 0.168 & 0.171 & 0.157 & 0.133 & 0.213 \\
\hline $\mathrm{Na}_{2} \mathrm{O}$ & 0.003 & 0.003 & 0.002 & 0.001 & 0.001 & 0.000 & 0.001 \\
\hline $\mathrm{K}_{2} \mathrm{O}$ & 0.008 & 0.004 & 0.002 & 0.001 & 0.002 & 0.000 & 0.015 \\
\hline $\mathrm{Al}_{2} \mathrm{O}_{3}$ & 0.205 & 0.194 & 0.214 & 0.225 & 0.196 & 0.219 & 0.226 \\
\hline $\mathrm{MnO}$ & 0.003 & 0.006 & 0.012 & 0.011 & 0.009 & 0.016 & 0.002 \\
\hline $\mathrm{MgO}$ & 0.143 & 0.142 & 0.176 & 0.198 & 0.216 & 0.215 & 0.136 \\
\hline $\mathrm{CaO}$ & 0.019 & 0.001 & 0.001 & 0.000 & 0.001 & 0.000 & 0.000 \\
\hline $\mathrm{F}$ & 0.002 & 0.001 & 0.001 & 0.002 & 0.005 & 0.003 & 0.000 \\
\hline $\mathrm{Cr}_{2} \mathrm{O}_{3}$ & 0.000 & 0.001 & 0.000 & 0.000 & 0.000 & 0.000 & 0.000 \\
\hline $\mathrm{TiO}_{2}$ & 0.021 & 0.001 & 0.000 & 0.000 & 0.000 & 0.000 & 0.000 \\
\hline $\mathrm{ZnO}$ & 0.001 & 0.000 & 0.001 & 0.001 & 0.001 & 0.001 & 0.002 \\
\hline $\mathrm{V}_{2} \mathrm{O}_{3}$ & 0.000 & 0.001 & 0.000 & 0.000 & 0.000 & 0.000 & 0.001 \\
\hline $\mathrm{H}_{2} \mathrm{O}$ & 0.112 & 0.115 & 0.111 & 0.116 & 0.114 & 0.114 & 0.113 \\
\hline $\mathrm{F}=\mathrm{O}$ & -0.002 & -0.001 & -0.001 & -0.002 & -0.003 & -0.001 & 0 \\
\hline Total & 0.972 & 0.983 & 0.937 & 0.983 & 0.975 & 0.956 & 0.971 \\
\hline $\mathrm{Si}$ & 5.459 & 6.153 & 5.384 & 5.300 & 5.616 & 5.314 & 5.585 \\
\hline $\mathrm{Fe}$ & 3.509 & 3.824 & 3.032 & 2.934 & 2.708 & 2.311 & 3.776 \\
\hline $\mathrm{Na}$ & 0.128 & 0.117 & 0.088 & 0.032 & 0.043 & 0.018 & 0.022 \\
\hline $\mathrm{K}$ & 0.220 & 0.100 & 0.056 & 0.022 & 0.049 & 0.010 & 0.394 \\
\hline $\mathrm{Al}$ & 5.130 & 4.774 & 5.458 & 5.440 & 4.768 & 5.369 & 5.647 \\
\hline Mn & 0.062 & 0.104 & 0.215 & 0.195 & 0.159 & 0.286 & 0.042 \\
\hline
\end{tabular}




\begin{tabular}{|c|c|c|c|c|c|c|c|}
\hline & \multicolumn{7}{|c|}{ Samples } \\
\hline & K254 & K258 & KA25-9 & KA25-10 & KA25-11 & KA25-m & KA25-14 \\
\hline $\mathrm{Mg}$ & 4.544 & 4.431 & 5.679 & 6.054 & 6.642 & 6.664 & 4.288 \\
\hline $\mathrm{Ca}$ & 0.432 & 0.014 & 0.018 & 0.006 & 0.014 & 0.007 & 0.000 \\
\hline $\mathrm{Cr}$ & 0.002 & 0.009 & 0.004 & 0.002 & 0.005 & 0.002 & 0.000 \\
\hline $\mathrm{Ti}$ & 0.323 & 0.010 & 0.002 & 0.007 & 0.007 & 0.004 & 0.005 \\
\hline $\mathrm{Zn}$ & 0.016 & 0.003 & 0.012 & 0.008 & 0.019 & 0.020 & 0.024 \\
\hline $\mathrm{V}$ & 0.001 & 0.010 & 0.003 & 0.000 & 0.004 & 0.004 & 0.010 \\
\hline $\mathrm{F}$ & 0.118 & 0.077 & 0.035 & 0.106 & 0.300 & 0.194 & 0.000 \\
\hline $\mathrm{OH}$ & 15.882 & 15.923 & 15.965 & 15.894 & 15.700 & 15.806 & 16.000 \\
\hline FM & 0.446 & 0.470 & 0.362 & 0.341 & 0.301 & 0.280 & 0.471 \\
\hline
\end{tabular}

Table 3b. Chemical compositions of white mica within argillite of DDH KA25.

\begin{tabular}{|c|c|c|c|c|c|c|c|c|c|c|}
\hline & \multicolumn{10}{|c|}{ Samples } \\
\hline & $\begin{array}{l}\text { KA25 } \\
-4\end{array}$ & $\begin{array}{l}\text { KA25 } \\
-7\end{array}$ & $\begin{array}{l}\text { KA25 } \\
-8\end{array}$ & $\begin{array}{l}\text { KA25 } \\
-9\end{array}$ & $\begin{array}{l}\text { KA25 } \\
-10\end{array}$ & $\begin{array}{l}\text { KA25 } \\
-11\end{array}$ & $\begin{array}{l}\text { KA25 } \\
-\mathbf{m}\end{array}$ & $\begin{array}{l}\text { KA25 } \\
-12\end{array}$ & $\begin{array}{l}\text { KA25 } \\
-13\end{array}$ & $\begin{array}{l}\text { KA25 } \\
-14\end{array}$ \\
\hline $\begin{array}{l}\text { Distan } \\
\text { ce }(\mathrm{m})\end{array}$ & 336.9 & 362.5 & 368.5 & 396.3 & $\begin{array}{l}397.0 \\
5\end{array}$ & 398 & $\begin{array}{l}421.4 \\
5\end{array}$ & 423.9 & $\begin{array}{l}425.0 \\
5\end{array}$ & $\begin{array}{l}427.1 \\
5\end{array}$ \\
\hline$N$ & 2 & 3 & 2 & 2 & 7 & 8 & 4 & 15 & 19 & 10 \\
\hline $\mathrm{SiO}_{2}$ & $\begin{array}{l}44.94 \\
50\end{array}$ & $\begin{array}{l}46.83 \\
00\end{array}$ & $\begin{array}{l}39.86 \\
50\end{array}$ & $\begin{array}{l}43.32 \\
50\end{array}$ & $\begin{array}{l}48.09 \\
00\end{array}$ & $\begin{array}{l}45.56 \\
38\end{array}$ & $\begin{array}{l}44.51 \\
75\end{array}$ & $\begin{array}{l}46.22 \\
47\end{array}$ & $\begin{array}{l}43.47 \\
11\end{array}$ & $\begin{array}{l}44.23 \\
00\end{array}$ \\
\hline $\mathrm{FeO}$ & $\begin{array}{l}1.020 \\
0\end{array}$ & $\begin{array}{l}1.060 \\
0\end{array}$ & $\begin{array}{l}1.725 \\
0\end{array}$ & $\begin{array}{l}1.185 \\
0\end{array}$ & $\begin{array}{l}1.012 \\
9\end{array}$ & $\begin{array}{l}0.757 \\
5\end{array}$ & $\begin{array}{l}2.270 \\
0\end{array}$ & $\begin{array}{l}2.000 \\
0\end{array}$ & $\begin{array}{l}1.942 \\
6\end{array}$ & $\begin{array}{l}3.414 \\
0\end{array}$ \\
\hline $\mathrm{Na}_{2} \mathrm{O}$ & $\begin{array}{l}0.480 \\
0\end{array}$ & $\begin{array}{l}1.096 \\
7\end{array}$ & $\begin{array}{l}0.175 \\
0\end{array}$ & $\begin{array}{l}1.470 \\
0\end{array}$ & $\begin{array}{l}0.461 \\
4\end{array}$ & $\begin{array}{l}0.611 \\
3\end{array}$ & $\begin{array}{l}0.415 \\
0\end{array}$ & $\begin{array}{l}0.370 \\
0\end{array}$ & $\begin{array}{l}0.706 \\
8\end{array}$ & $\begin{array}{l}0.449 \\
0\end{array}$ \\
\hline $\mathrm{K}_{2} \mathrm{O}$ & $\begin{array}{l}9.610 \\
0\end{array}$ & $\begin{array}{l}8.743 \\
3\end{array}$ & $\begin{array}{l}8.725 \\
0\end{array}$ & $\begin{array}{l}7.705 \\
0\end{array}$ & $\begin{array}{l}9.167 \\
1\end{array}$ & $\begin{array}{l}9.738 \\
8\end{array}$ & $\begin{array}{l}9.147 \\
5\end{array}$ & $\begin{array}{l}9.722 \\
7\end{array}$ & $\begin{array}{l}9.358 \\
9\end{array}$ & $\begin{array}{l}8.682 \\
0\end{array}$ \\
\hline $\mathrm{Al}_{2} \mathrm{O}_{3}$ & $\begin{array}{l}35.59 \\
50\end{array}$ & $\begin{array}{l}31.83 \\
67\end{array}$ & $\begin{array}{l}28.01 \\
50\end{array}$ & $\begin{array}{l}31.47 \\
00\end{array}$ & $\begin{array}{l}31.30 \\
71\end{array}$ & $\begin{array}{l}33.04 \\
13\end{array}$ & $\begin{array}{l}32.60 \\
50\end{array}$ & $\begin{array}{l}32.69 \\
60\end{array}$ & $\begin{array}{l}33.36 \\
37\end{array}$ & $\begin{array}{l}30.61 \\
20\end{array}$ \\
\hline $\mathrm{MnO}$ & $\begin{array}{l}0.020 \\
0\end{array}$ & $\begin{array}{l}0.046 \\
7\end{array}$ & $\begin{array}{l}0.025 \\
0\end{array}$ & $\begin{array}{l}0.300 \\
0\end{array}$ & $\begin{array}{l}0.032 \\
9\end{array}$ & $\begin{array}{l}0.037 \\
5\end{array}$ & $\begin{array}{l}0.172 \\
5\end{array}$ & $\begin{array}{l}0.036 \\
0\end{array}$ & $\begin{array}{l}0.025 \\
3\end{array}$ & $\begin{array}{l}0.039 \\
0\end{array}$ \\
\hline $\mathrm{MgO}$ & 0.880 & 0.986 & 1.600 & 0.340 & 1.274 & 1.383 & 2.827 & 1.560 & 1.477 & 2.376 \\
\hline
\end{tabular}




\begin{tabular}{|c|c|c|c|c|c|c|c|c|c|c|}
\hline & \multicolumn{10}{|c|}{ Samples } \\
\hline & $\begin{array}{l}\text { KA25 } \\
-4\end{array}$ & $\begin{array}{l}\text { KA25 } \\
-7\end{array}$ & $\begin{array}{l}\text { KA25 } \\
-8\end{array}$ & $\begin{array}{l}\text { KA25 } \\
-9\end{array}$ & $\begin{array}{l}\text { KA25 } \\
-10\end{array}$ & $\begin{array}{l}\text { KA25 } \\
-11\end{array}$ & $\begin{array}{l}\text { KA25 } \\
-\mathbf{m}\end{array}$ & $\begin{array}{l}\text { KA25 } \\
-12\end{array}$ & $\begin{array}{l}\text { KA25 } \\
-13\end{array}$ & $\begin{array}{l}\text { KA25 } \\
-14\end{array}$ \\
\hline & 0 & 7 & 0 & 0 & 3 & 8 & 5 & 7 & 4 & 0 \\
\hline $\mathrm{CaO}$ & $\begin{array}{l}0.060 \\
0\end{array}$ & $\begin{array}{l}1.240 \\
0\end{array}$ & $\begin{array}{l}0.025 \\
0\end{array}$ & $\begin{array}{l}1.115 \\
0\end{array}$ & $\begin{array}{l}0.085 \\
7\end{array}$ & $\begin{array}{l}0.031 \\
3\end{array}$ & $\begin{array}{l}0.017 \\
5\end{array}$ & $\begin{array}{l}0.043 \\
3\end{array}$ & $\begin{array}{l}0.270 \\
0\end{array}$ & $\begin{array}{l}0.022 \\
0\end{array}$ \\
\hline $\mathrm{F}$ & $\begin{array}{l}0.080 \\
0\end{array}$ & $\begin{array}{l}0.030 \\
0\end{array}$ & $\begin{array}{l}0.265 \\
0\end{array}$ & $\begin{array}{l}0.030 \\
0\end{array}$ & $\begin{array}{l}0.138 \\
6\end{array}$ & $\begin{array}{l}0.220 \\
0\end{array}$ & $\begin{array}{l}0.237 \\
5\end{array}$ & $\begin{array}{l}0.125 \\
3\end{array}$ & $\begin{array}{l}0.250 \\
0\end{array}$ & $\begin{array}{l}0.207 \\
0\end{array}$ \\
\hline $\mathrm{Cr}_{2} \mathrm{O}_{3}$ & $\begin{array}{l}0.020 \\
0\end{array}$ & $\begin{array}{l}0.093 \\
3\end{array}$ & $\begin{array}{l}0.030 \\
0\end{array}$ & $\begin{array}{l}0.000 \\
0\end{array}$ & $\begin{array}{l}0.017 \\
1\end{array}$ & $\begin{array}{l}0.015 \\
0\end{array}$ & $\begin{array}{l}0.020 \\
0\end{array}$ & $\begin{array}{l}0.025 \\
3\end{array}$ & $\begin{array}{l}0.023 \\
2\end{array}$ & $\begin{array}{l}0.016 \\
0\end{array}$ \\
\hline $\mathrm{TiO}_{2}$ & $\begin{array}{l}0.305 \\
0\end{array}$ & $\begin{array}{l}0.363 \\
3\end{array}$ & $\begin{array}{l}0.700 \\
0\end{array}$ & $\begin{array}{l}0.040 \\
0\end{array}$ & $\begin{array}{l}0.492 \\
9\end{array}$ & $\begin{array}{l}0.526 \\
3\end{array}$ & $\begin{array}{l}0.360 \\
0\end{array}$ & $\begin{array}{l}0.478 \\
7\end{array}$ & $\begin{array}{l}0.455 \\
3\end{array}$ & $\begin{array}{l}1.345 \\
0\end{array}$ \\
\hline $\mathrm{ZnO}$ & $\begin{array}{l}0.050 \\
0\end{array}$ & $\begin{array}{l}0.000 \\
0\end{array}$ & $\begin{array}{l}0.000 \\
0\end{array}$ & $\begin{array}{l}0.020 \\
0\end{array}$ & $\begin{array}{l}0.022 \\
9\end{array}$ & $\begin{array}{l}0.013 \\
8\end{array}$ & $\begin{array}{l}0.005 \\
0\end{array}$ & $\begin{array}{l}0.048 \\
0\end{array}$ & $\begin{array}{l}0.064 \\
7\end{array}$ & $\begin{array}{l}0.055 \\
0\end{array}$ \\
\hline $\mathrm{V}_{2} \mathrm{O}_{3}$ & $\begin{array}{l}0.015 \\
0\end{array}$ & $\begin{array}{l}0.070 \\
0\end{array}$ & $\begin{array}{l}0.045 \\
0\end{array}$ & $\begin{array}{l}0.000 \\
0\end{array}$ & $\begin{array}{l}0.035 \\
7\end{array}$ & $\begin{array}{l}0.048 \\
8\end{array}$ & $\begin{array}{l}0.077 \\
5\end{array}$ & $\begin{array}{l}0.044 \\
7\end{array}$ & $\begin{array}{l}0.041 \\
1\end{array}$ & $\begin{array}{l}0.040 \\
0\end{array}$ \\
\hline $\mathrm{H}_{2} \mathrm{O}$ & $\begin{array}{l}4.385 \\
0\end{array}$ & $\begin{array}{l}4.376 \\
7\end{array}$ & $\begin{array}{l}3.690 \\
0\end{array}$ & $\begin{array}{l}4.120 \\
0\end{array}$ & $\begin{array}{l}4.337 \\
1\end{array}$ & $\begin{array}{l}4.255 \\
0\end{array}$ & $\begin{array}{l}4.242 \\
5\end{array}$ & $\begin{array}{l}4.347 \\
3\end{array}$ & $\begin{array}{l}4.174 \\
7\end{array}$ & $\begin{array}{l}4.186 \\
0\end{array}$ \\
\hline $\mathrm{F}=\mathrm{O}$ & $\begin{array}{l}-0.07 \\
00\end{array}$ & $\begin{array}{l}-0.04 \\
00\end{array}$ & $\begin{array}{l}-0.22 \\
00\end{array}$ & $\begin{array}{l}-0.02 \\
00\end{array}$ & $\begin{array}{l}-0.08 \\
20\end{array}$ & $\begin{array}{l}-0.12 \\
50\end{array}$ & $\begin{array}{l}-0.10 \\
25\end{array}$ & $\begin{array}{l}-0.06 \\
58\end{array}$ & $\begin{array}{l}-0.14 \\
43\end{array}$ & $\begin{array}{l}-0.10 \\
88\end{array}$ \\
\hline Total & $\begin{array}{l}97.43 \\
50\end{array}$ & $\begin{array}{l}96.77 \\
00\end{array}$ & $\begin{array}{l}84.77 \\
00\end{array}$ & $\begin{array}{l}91.11 \\
00\end{array}$ & $\begin{array}{l}96.41 \\
29\end{array}$ & $\begin{array}{l}96.15 \\
50\end{array}$ & $\begin{array}{l}96.81 \\
50\end{array}$ & $\begin{array}{l}97.67 \\
13\end{array}$ & $\begin{array}{l}95.51 \\
95\end{array}$ & $\begin{array}{l}95.58 \\
60\end{array}$ \\
\hline $\mathrm{Si}$ & $\begin{array}{l}6.097 \\
4\end{array}$ & $\begin{array}{l}6.392 \\
7\end{array}$ & $\begin{array}{l}6.262 \\
7\end{array}$ & $\begin{array}{l}6.289 \\
8\end{array}$ & $\begin{array}{l}6.549 \\
5\end{array}$ & $\begin{array}{l}6.268 \\
0\end{array}$ & $\begin{array}{l}6.123 \\
5\end{array}$ & $\begin{array}{l}6.283 \\
1\end{array}$ & $\begin{array}{l}6.064 \\
3\end{array}$ & $\begin{array}{l}6.186 \\
4\end{array}$ \\
\hline $\mathrm{Fe}$ & $\begin{array}{l}0.115 \\
0\end{array}$ & $\begin{array}{l}0.121 \\
6\end{array}$ & $\begin{array}{l}0.226 \\
8\end{array}$ & $\begin{array}{l}0.141 \\
7\end{array}$ & $\begin{array}{l}0.115 \\
4\end{array}$ & $\begin{array}{l}0.087 \\
4\end{array}$ & $\begin{array}{l}0.266 \\
2\end{array}$ & $\begin{array}{l}0.228 \\
6\end{array}$ & $\begin{array}{l}0.225 \\
3\end{array}$ & $\begin{array}{l}0.404 \\
7\end{array}$ \\
\hline $\mathrm{Na}$ & $\begin{array}{l}0.126 \\
3\end{array}$ & $\begin{array}{l}0.286 \\
3\end{array}$ & $\begin{array}{l}0.053 \\
2\end{array}$ & $\begin{array}{l}0.415 \\
3\end{array}$ & $\begin{array}{l}0.121 \\
9\end{array}$ & $\begin{array}{l}0.164 \\
4\end{array}$ & $\begin{array}{l}0.110 \\
6\end{array}$ & $\begin{array}{l}0.097 \\
7\end{array}$ & $\begin{array}{l}0.193 \\
6\end{array}$ & $\begin{array}{l}0.122 \\
5\end{array}$ \\
\hline K & $\begin{array}{l}1.664 \\
6\end{array}$ & $\begin{array}{l}1.530 \\
1\end{array}$ & $\begin{array}{l}1.753 \\
0\end{array}$ & $\begin{array}{l}1.424 \\
9\end{array}$ & $\begin{array}{l}1.593 \\
3\end{array}$ & $\begin{array}{l}1.709 \\
5\end{array}$ & $\begin{array}{l}1.602 \\
3\end{array}$ & $\begin{array}{l}1.688 \\
6\end{array}$ & $\begin{array}{l}1.669 \\
5\end{array}$ & $\begin{array}{l}1.547 \\
3\end{array}$ \\
\hline $\mathrm{Al}$ & $\begin{array}{l}5.687 \\
8\end{array}$ & $\begin{array}{l}5.130 \\
8\end{array}$ & $\begin{array}{l}5.189 \\
0\end{array}$ & $\begin{array}{l}5.377 \\
5\end{array}$ & $\begin{array}{l}5.028 \\
0\end{array}$ & $\begin{array}{l}5.351 \\
0\end{array}$ & $\begin{array}{l}5.284 \\
4\end{array}$ & $\begin{array}{l}5.245 \\
7\end{array}$ & $\begin{array}{l}5.499 \\
4\end{array}$ & $\begin{array}{l}5.047 \\
6\end{array}$ \\
\hline $\mathrm{Mn}$ & 0.002 & 0.005 & 0.003 & 0.036 & 0.003 & 0.004 & 0.020 & 0.004 & 0.003 & 0.004 \\
\hline
\end{tabular}




\begin{tabular}{|c|c|c|c|c|c|c|c|c|c|c|}
\hline & \multicolumn{10}{|c|}{ Samples } \\
\hline & $\begin{array}{l}\text { KA25 } \\
-4\end{array}$ & $\begin{array}{l}\text { KA25 } \\
-7\end{array}$ & $\begin{array}{l}\text { KA25 } \\
-8\end{array}$ & $\begin{array}{l}\text { KA25 } \\
-9\end{array}$ & $\begin{array}{l}\text { KA25 } \\
-10\end{array}$ & $\begin{array}{l}\text { KA25 } \\
-11\end{array}$ & $\begin{array}{l}\text { KA25 } \\
-\mathbf{m}\end{array}$ & $\begin{array}{l}\text { KA25 } \\
-12\end{array}$ & $\begin{array}{l}\text { KA25 } \\
-13\end{array}$ & $\begin{array}{l}\text { KA25 } \\
-14\end{array}$ \\
\hline & 6 & 3 & 1 & 4 & 8 & 3 & 8 & 1 & 1 & 7 \\
\hline $\mathrm{Mg}$ & $\begin{array}{l}0.178 \\
3\end{array}$ & $\begin{array}{l}0.203 \\
3\end{array}$ & $\begin{array}{l}0.373 \\
9\end{array}$ & $\begin{array}{l}0.071 \\
6\end{array}$ & $\begin{array}{l}0.258 \\
5\end{array}$ & $\begin{array}{l}0.284 \\
0\end{array}$ & $\begin{array}{l}0.588 \\
6\end{array}$ & $\begin{array}{l}0.318 \\
3\end{array}$ & $\begin{array}{l}0.306 \\
7\end{array}$ & $\begin{array}{l}0.503 \\
6\end{array}$ \\
\hline $\mathrm{Ca}$ & $\begin{array}{l}0.008 \\
7\end{array}$ & $\begin{array}{l}0.177 \\
3\end{array}$ & $\begin{array}{l}0.004 \\
0\end{array}$ & $\begin{array}{l}0.173 \\
2\end{array}$ & $\begin{array}{l}0.012 \\
5\end{array}$ & $\begin{array}{l}0.004 \\
6\end{array}$ & $\begin{array}{l}0.002 \\
7\end{array}$ & $\begin{array}{l}0.006 \\
4\end{array}$ & $\begin{array}{l}0.042 \\
1\end{array}$ & $\begin{array}{l}0.003 \\
3\end{array}$ \\
\hline $\mathrm{C}$ & $\begin{array}{l}0.002 \\
0\end{array}$ & $\begin{array}{l}0.010 \\
4\end{array}$ & $\begin{array}{l}0.003 \\
9\end{array}$ & $\begin{array}{l}0.000 \\
0\end{array}$ & $\begin{array}{l}0.001 \\
8\end{array}$ & $\begin{array}{l}0.001 \\
6\end{array}$ & $\begin{array}{l}0.002 \\
3\end{array}$ & $\begin{array}{l}0.002 \\
8\end{array}$ & $\begin{array}{l}0.002 \\
5\end{array}$ & $\begin{array}{l}0.002 \\
0\end{array}$ \\
\hline $\mathrm{TI}$ & $\begin{array}{l}0.031 \\
7\end{array}$ & $\begin{array}{l}0.037 \\
9\end{array}$ & $\begin{array}{l}0.082 \\
9\end{array}$ & $\begin{array}{l}0.004 \\
4\end{array}$ & $\begin{array}{l}0.050 \\
3\end{array}$ & $\begin{array}{l}0.054 \\
4\end{array}$ & $\begin{array}{l}0.037 \\
2\end{array}$ & $\begin{array}{l}0.049 \\
1\end{array}$ & $\begin{array}{l}0.048 \\
1\end{array}$ & $\begin{array}{l}0.144 \\
6\end{array}$ \\
\hline $\mathrm{Zn}$ & $\begin{array}{l}0.005 \\
2\end{array}$ & $\begin{array}{l}0.000 \\
0\end{array}$ & $\begin{array}{l}0.000 \\
0\end{array}$ & $\begin{array}{l}0.002 \\
4\end{array}$ & $\begin{array}{l}0.002 \\
2\end{array}$ & $\begin{array}{l}0.001 \\
3\end{array}$ & $\begin{array}{l}0.000 \\
6\end{array}$ & $\begin{array}{l}0.004 \\
8\end{array}$ & $\begin{array}{l}0.006 \\
5\end{array}$ & $\begin{array}{l}0.005 \\
8\end{array}$ \\
\hline V & $\begin{array}{l}0.001 \\
3\end{array}$ & $\begin{array}{l}0.007 \\
6\end{array}$ & $\begin{array}{l}0.005 \\
9\end{array}$ & $\begin{array}{l}0.000 \\
0\end{array}$ & $\begin{array}{l}0.003 \\
9\end{array}$ & $\begin{array}{l}0.005 \\
3\end{array}$ & $\begin{array}{l}0.008 \\
9\end{array}$ & $\begin{array}{l}0.005 \\
0\end{array}$ & $\begin{array}{l}0.004 \\
6\end{array}$ & $\begin{array}{l}0.004 \\
5\end{array}$ \\
\hline $\mathrm{F}$ & $\begin{array}{l}0.032 \\
9\end{array}$ & $\begin{array}{l}0.013 \\
6\end{array}$ & $\begin{array}{l}0.129 \\
6\end{array}$ & $\begin{array}{l}0.012 \\
4\end{array}$ & $\begin{array}{l}0.059 \\
5\end{array}$ & $\begin{array}{l}0.094 \\
7\end{array}$ & $\begin{array}{l}0.105 \\
0\end{array}$ & $\begin{array}{l}0.053 \\
5\end{array}$ & $\begin{array}{l}0.110 \\
1\end{array}$ & $\begin{array}{l}0.091 \\
2\end{array}$ \\
\hline $\mathrm{OH}$ & $\begin{array}{l}3.967 \\
1\end{array}$ & $\begin{array}{l}3.986 \\
4\end{array}$ & $\begin{array}{l}3.870 \\
5\end{array}$ & $\begin{array}{l}3.987 \\
7\end{array}$ & $\begin{array}{l}3.940 \\
5\end{array}$ & $\begin{array}{l}3.905 \\
3\end{array}$ & $\begin{array}{l}3.895 \\
1\end{array}$ & $\begin{array}{l}3.946 \\
5\end{array}$ & $\begin{array}{l}3.889 \\
9\end{array}$ & $\begin{array}{l}3.908 \\
8\end{array}$ \\
\hline FM & $\begin{array}{l}0.398 \\
3\end{array}$ & $\begin{array}{l}0.461 \\
1\end{array}$ & $\begin{array}{l}0.379 \\
4\end{array}$ & $\begin{array}{l}0.762 \\
7\end{array}$ & $\begin{array}{l}0.311 \\
3\end{array}$ & $\begin{array}{l}0.240 \\
8\end{array}$ & $\begin{array}{l}0.317 \\
8\end{array}$ & $\begin{array}{l}0.399 \\
4\end{array}$ & $\begin{array}{l}0.405 \\
3\end{array}$ & $\begin{array}{l}0.444 \\
1\end{array}$ \\
\hline
\end{tabular}



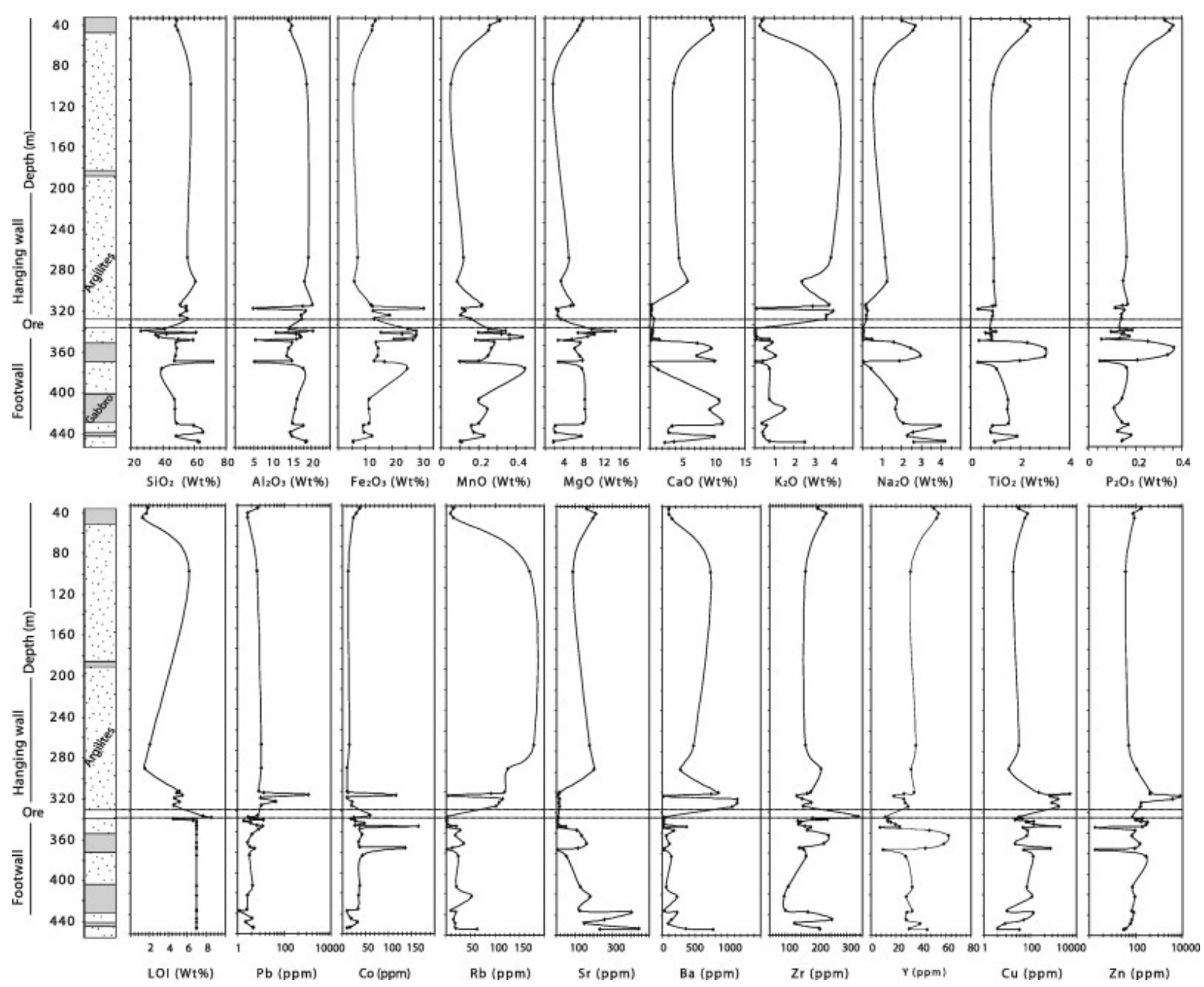

Fig. 3. : Lithogeochemical profile for DDH KA22b which intersects sulphide bodies as well as representative footwall and hanging wall lithofacies. 

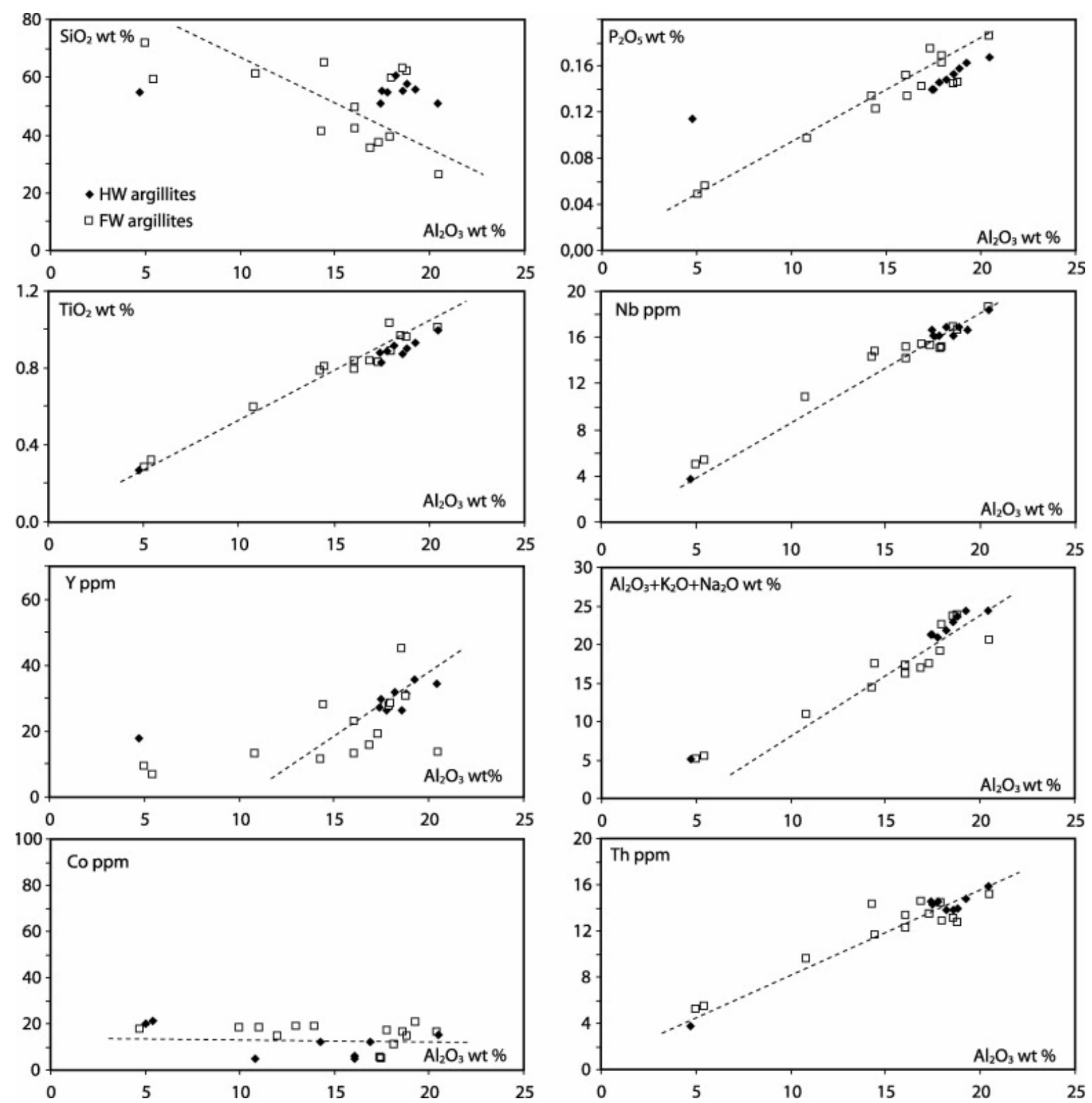

Fig. 4. : Diagrams showing the covariance between $\mathrm{Al}_{2} \mathrm{O}_{3}$ and selected major and trace elements of the argillites. 

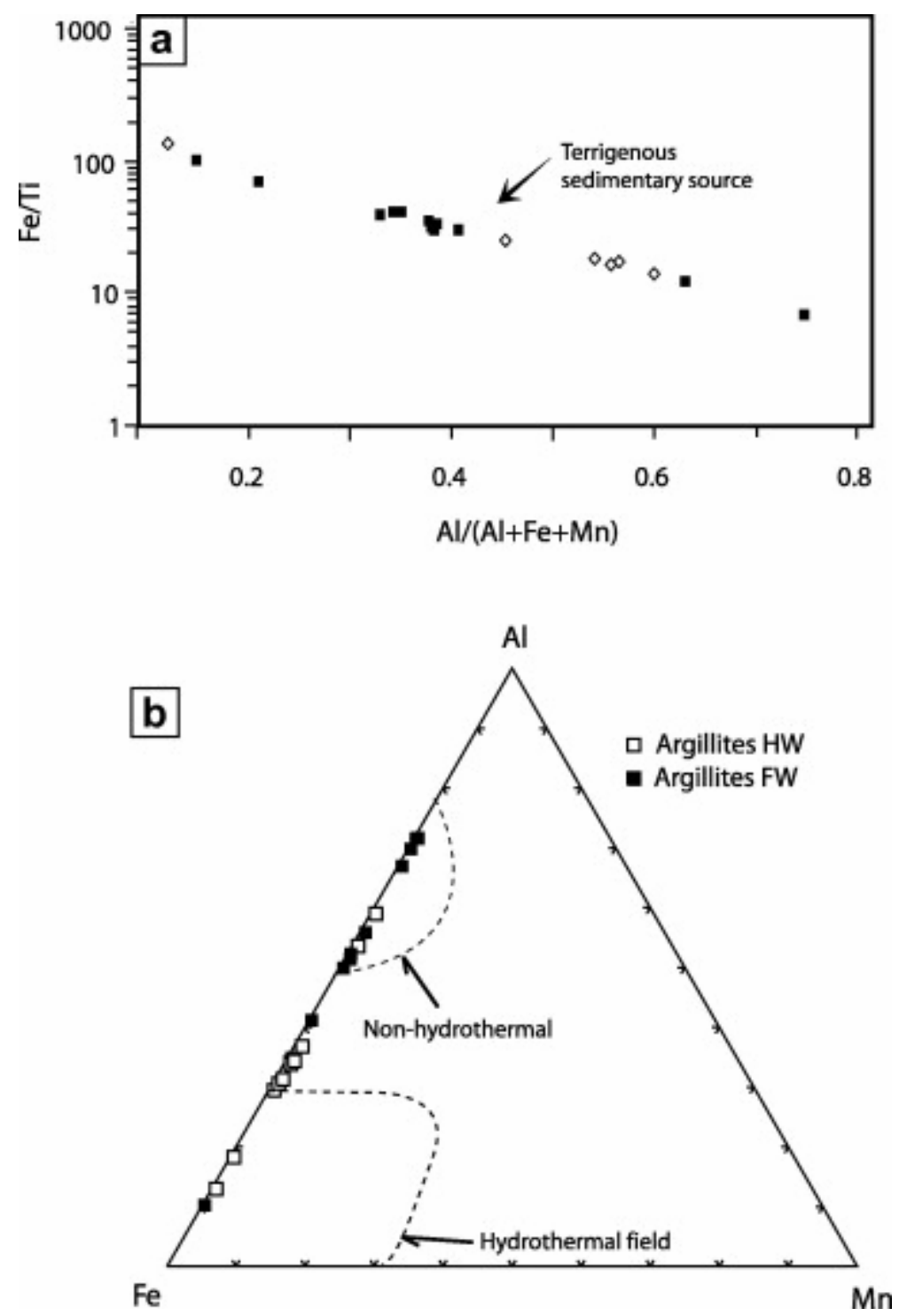

Fig. 5. : (a) $\mathrm{Al} /(\mathrm{Al}+\mathrm{Fe}+\mathrm{Mn})-(\mathrm{Fe} / \mathrm{Ti})$ for Koudiat Aïcha argillites (after Boström, 1973), illustrating the pronounced terrigenous contribution to these rocks. (b) Al-Fe-Mn ternary plots for Koudiat Aïcha argillites (footwall and hanging wall), showing hydrothermal and non-hydrothermal field (after Boström, 1973; see text). 

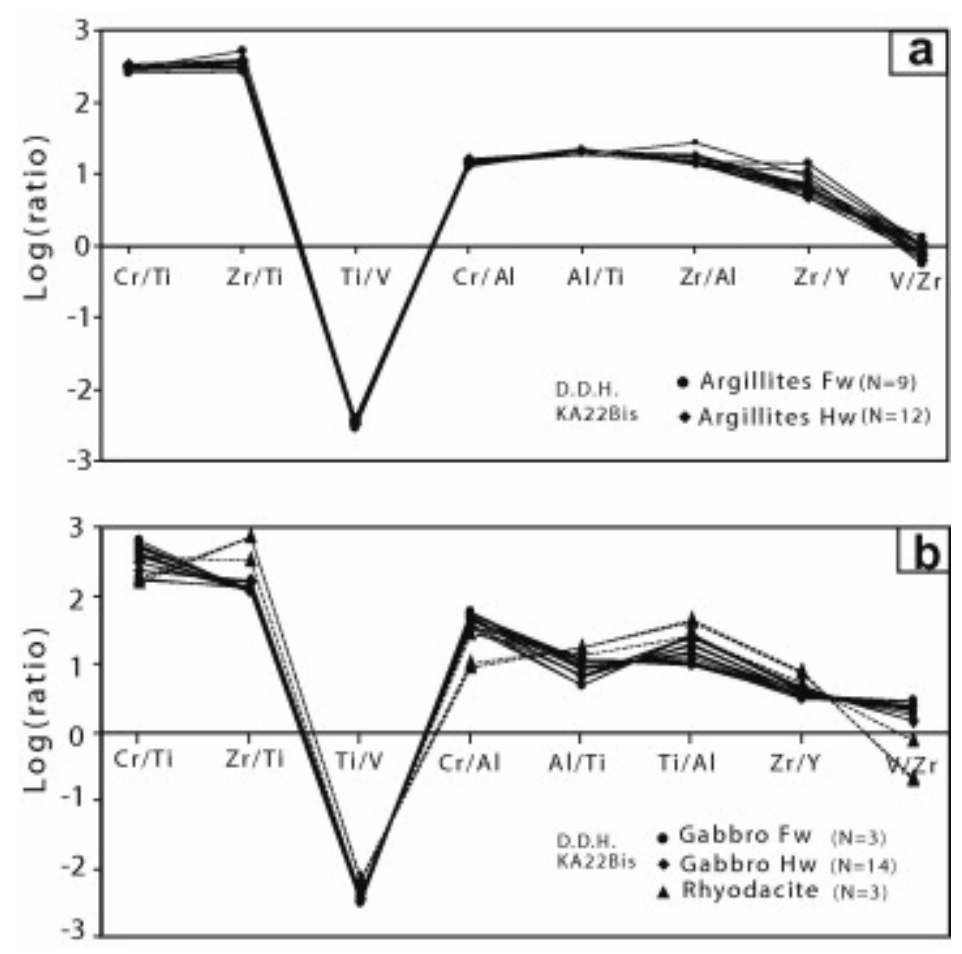

Fig. 6. : Geochemical log (ratio) method applied to Koudiat Aïcha argillites from DDH $\mathrm{KA} 22 \mathrm{~b}$, for (a) argillites and (b) gabbros. 

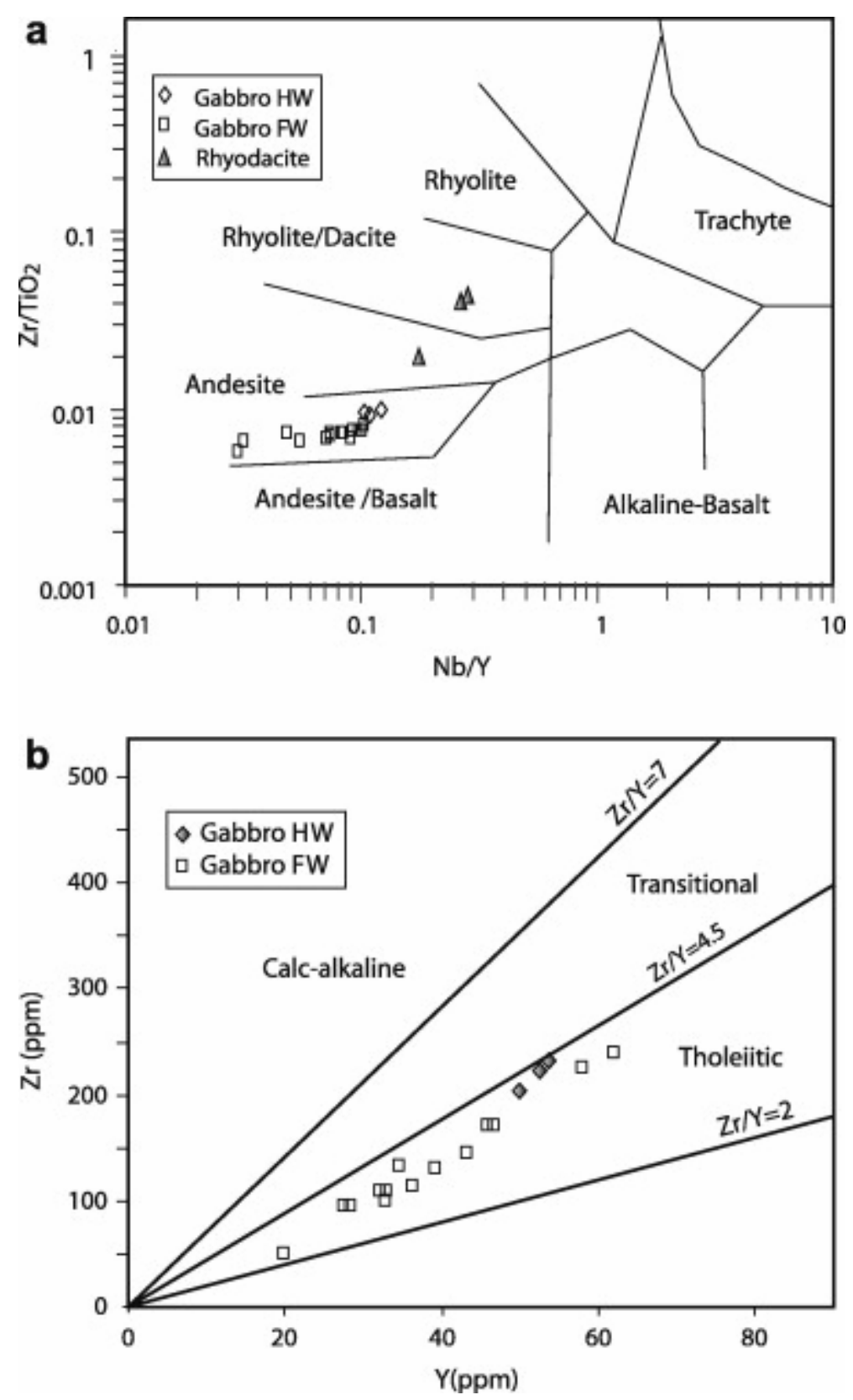

Fig. 7. : (a) Winchester and Floyd (1977) $\mathrm{Nb} / \mathrm{Y}$ versus $\mathrm{Zr} / \mathrm{TiO}_{2}$ classification diagram showing the rhyodacitic composition of felsic volcanic rocks and gabbros (hanging wall and footwall). (b) Y versus $\mathrm{Zr}$ discrimination diagram showing the tholeiitic affinity of rhyodacitic volcanic and gabbro rocks (divisions after Barrett and MacLean, 1999). 

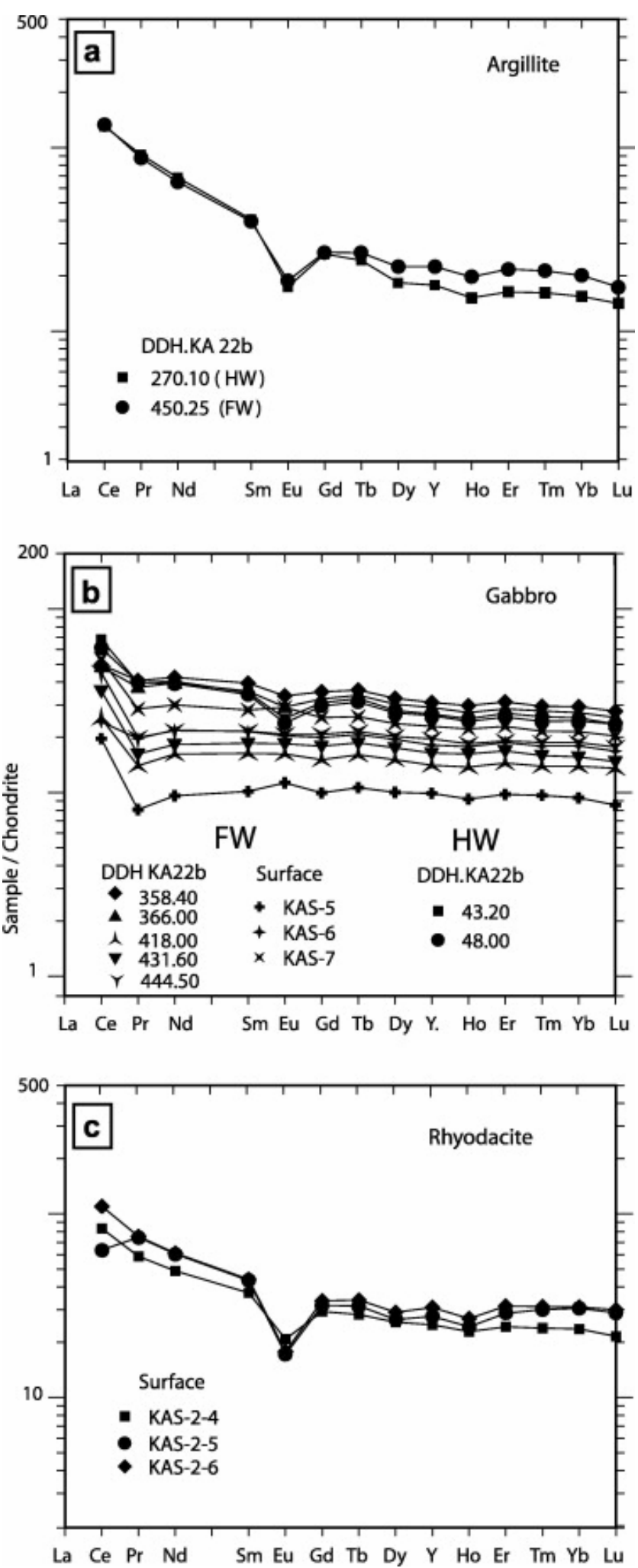

Fig. 8. : Chondrite-normalized, rare-earth element profiles for (a) argillite, (b) gabbro and (c) rhyodacite at Koudiat Aïcha. Chondrite-normalization values after Sun and McDonough, 1989 S.S. Sun and W.F. McDonough, Chemical and isotopic systematics of oceanic basalts: implications for mantle composition and processes. In: A.D. Saunders and M.J. Norry, Editors, Magmatism in the Ocean Basins, Geological Society of London (1989), pp. 313-345 (Special Publication 42). Sun and McDonough (1989) 


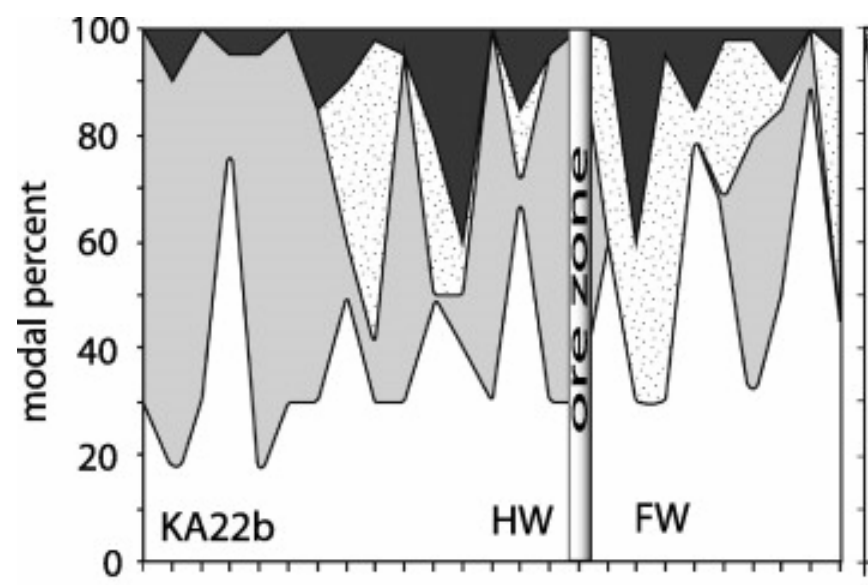

sample location

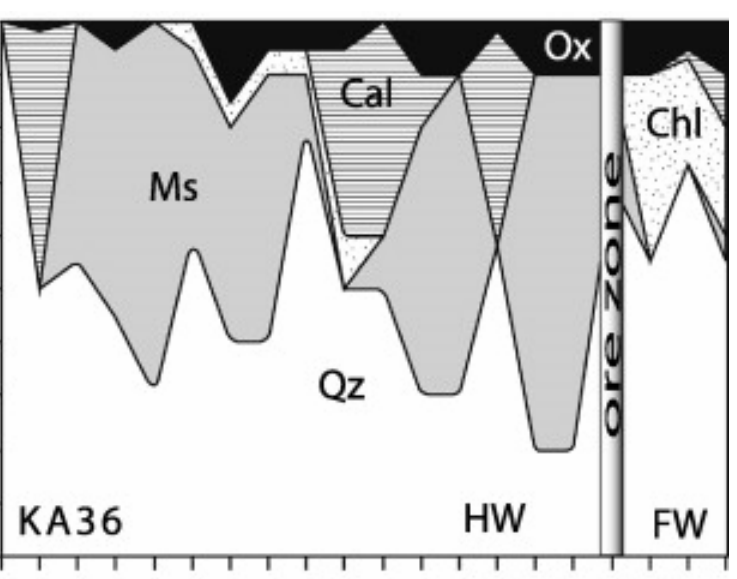

sample location

Fig. 9. : Variations in the modal percentage of major and minor minerals with distance above and below massive sulphide mineralization in (a) DDH KA22b and (b) DDH KA36 $(\mathrm{Chl}=$ chlorite, $\mathrm{Ox}=$ oxides and sulphides, $\mathrm{Qz}=$ quartz, $\mathrm{Cal}=$ calcite, $\mathrm{Ser}=$ sericite $)$.
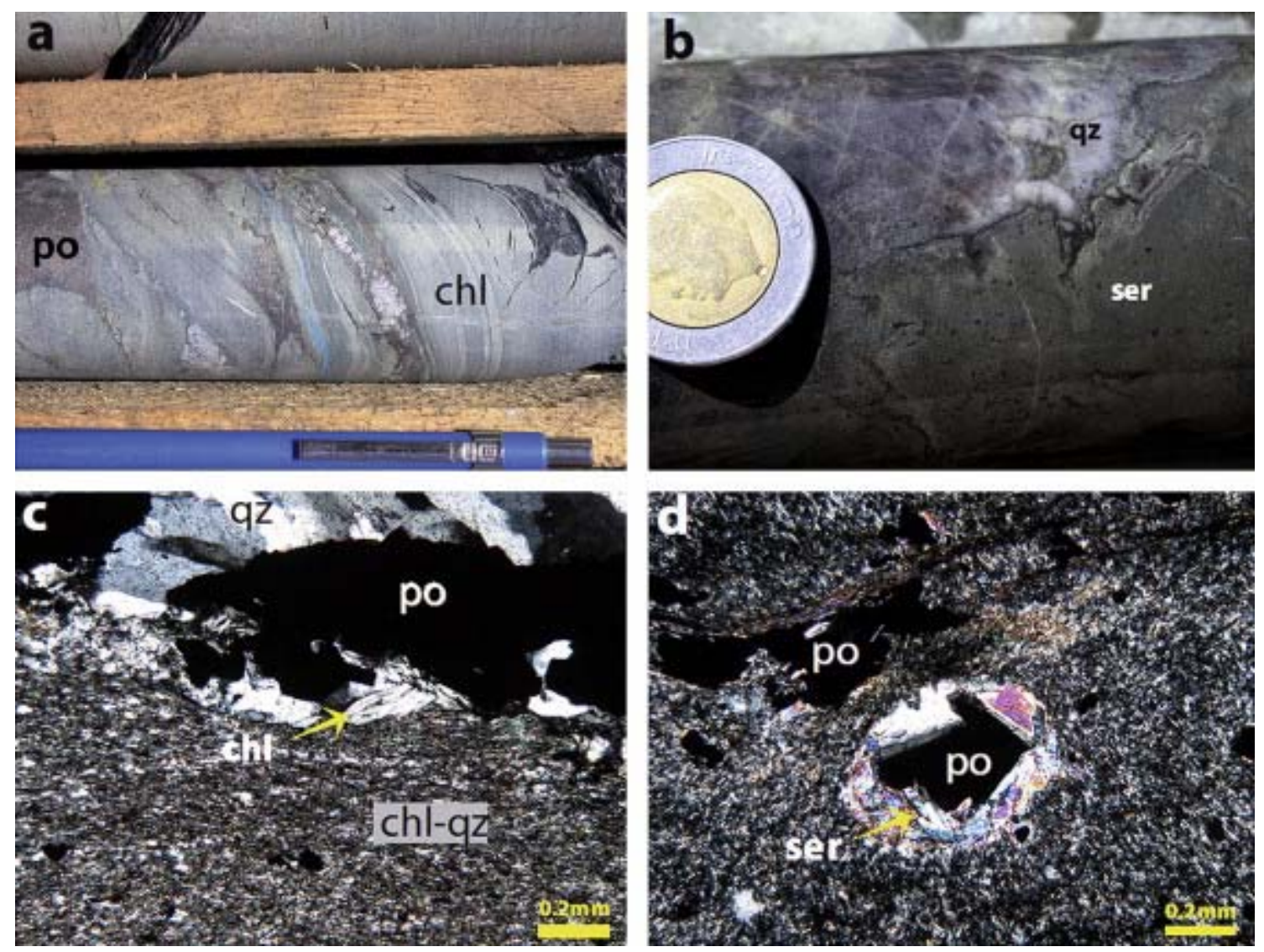

Fig. 10. : Macroscopic and textural features of (a) chloritic footwall sample showing an assemblage of chlorite (chl) slabs and pyrrhotite (po), (b) sericitic (with quartz) hanging wall alteration. Fine-scale structure of (c) chloritic footwall lithofacies and (d) sericitic hanging wall lithofacies. 

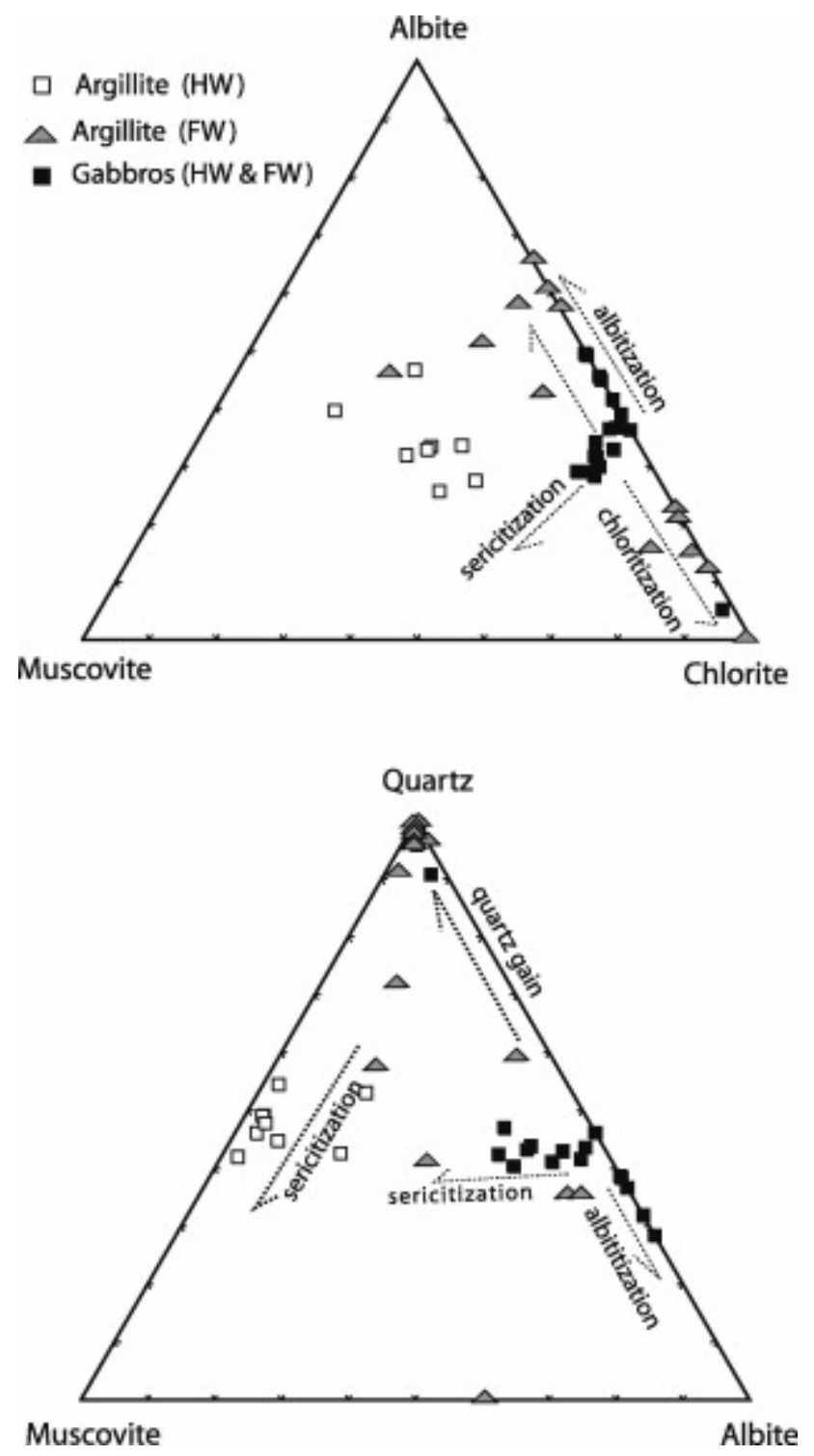

Fig. 11. : Triangular plots of cation normative alteration minerals from argillites and gabbros (footwall and hanging wall). The diagrams illustrate the chloritization, sericitization and breakdown of feldspar during hydrothermal alteration. 


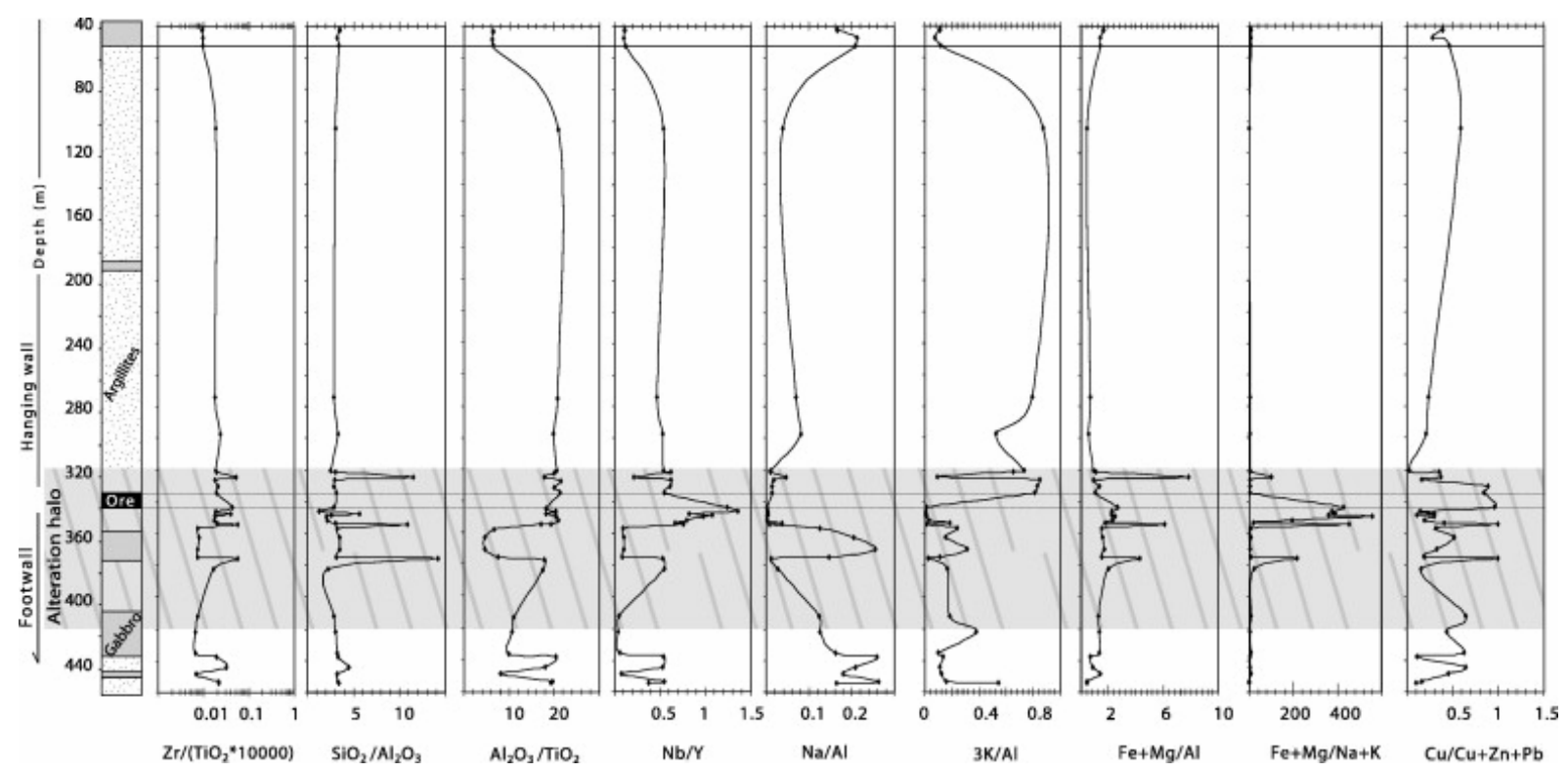

Fig. 12. : Lithogeochemical profiles of the alteration index along the DDH KA22b.

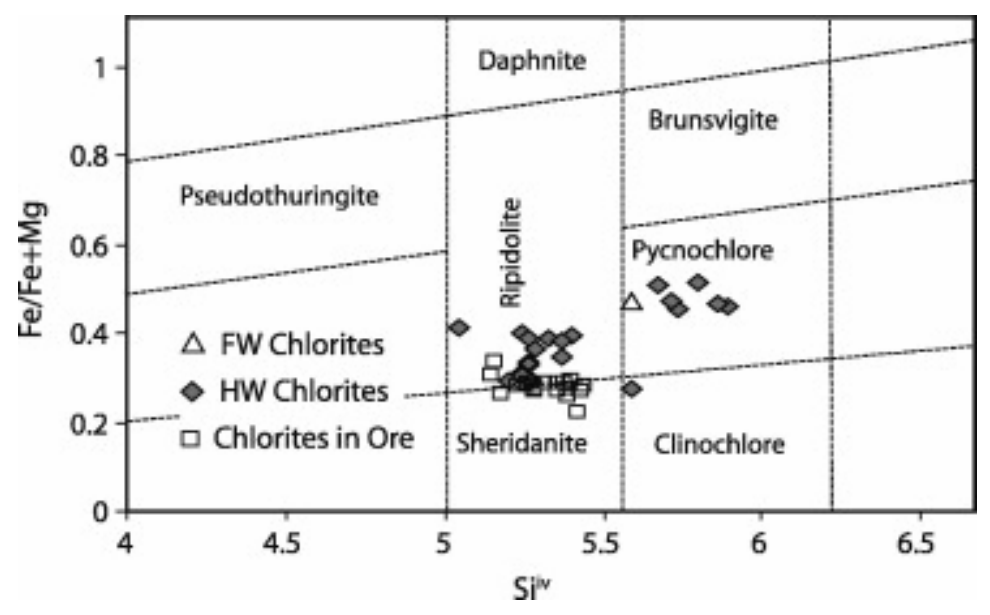

Fig. 13. : $\mathrm{Si}^{\mathrm{IV}}$ versus $\mathrm{Fe} / \mathrm{Fe}+\mathrm{Mg}$ plot of average chlorite compositions from the argillite lithofacies. Field boundaries after Hey (1954). 
Table 4. Temperature calculations using the chlorite geothermometer.

\begin{tabular}{|l|l|l|l|l|l|}
\hline Sample & Distance (m) & $\mathbf{F M ~ ( F e / ( F e ~ + ~ M g ) ) ~}$ & $\mathbf{A l}^{\text {IV }}$ uncorrected & $\mathbf{A l}^{\text {IV }}$ corrected & $\boldsymbol{T}\left({ }^{\circ} \mathbf{C}\right)$ \\
\hline KA 25-14 & 427.15 & 0.471 & 2.415 & 2.745 & 308 \\
\hline KA 25-m & 421.45 & 0.280 & 2.685 & 2.882 & 323 \\
\hline KA 25-11 & 398 & 0.301 & 2.384 & 2.595 & 293 \\
\hline KA 25-10 & 397.05 & 0.340 & 2.7 & 2.938 & 329 \\
\hline KA 25-9 & 396.3 & 0.361 & 2.615 & 2.86 & 322 \\
\hline KA 25-8 & 368.5 & 0.470 & 1.846 & 2.175 & 248 \\
\hline KA 25-4 & 336.9 & 0.446 & 2.541 & 2.853 & 320 \\
\hline
\end{tabular}
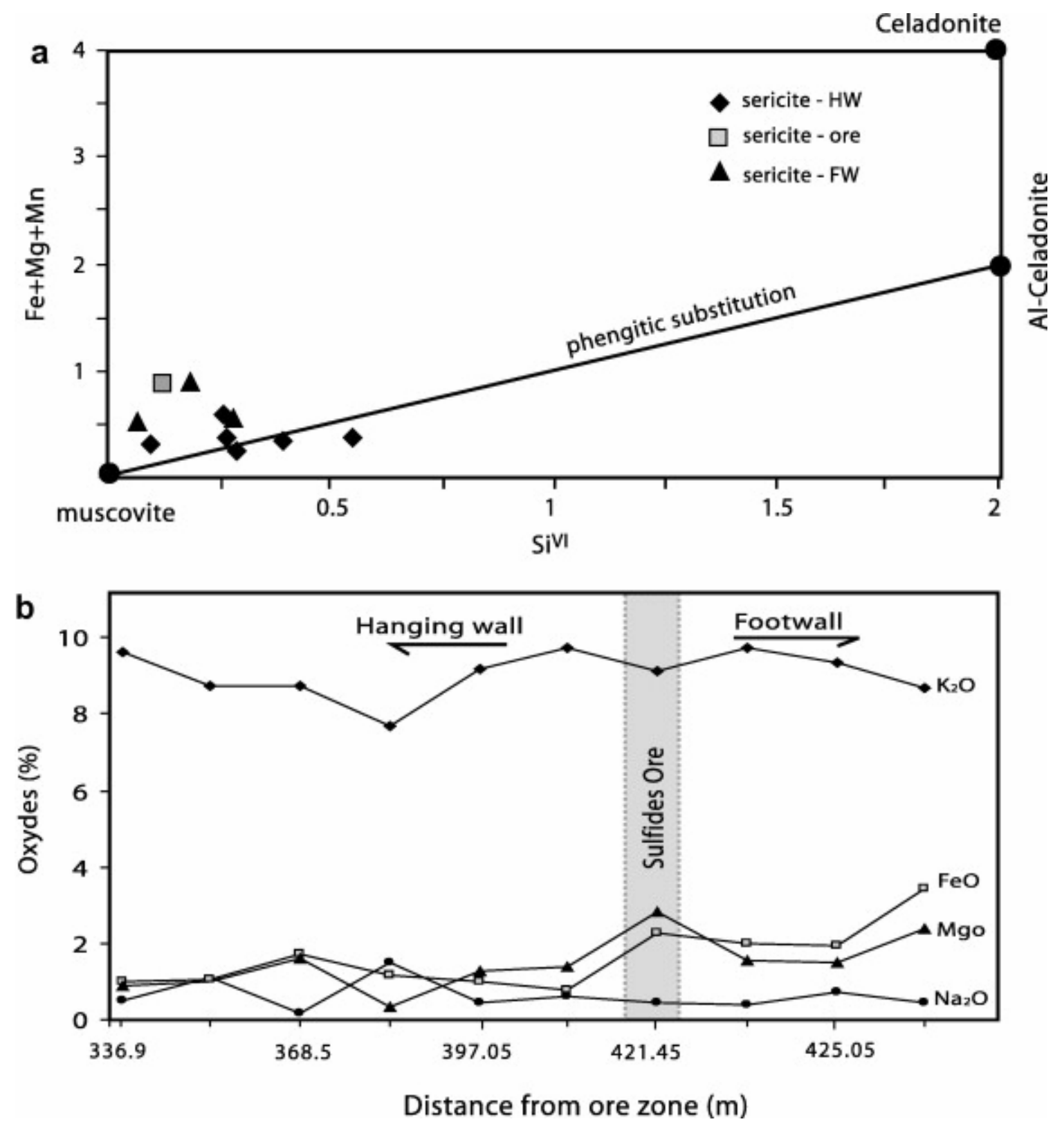
Fig. 14. : (a) Diagram after Velde (1977), showing $(\mathrm{Fe}+\mathrm{Mg}+\mathrm{Mn})$ versus $\mathrm{Si}^{\mathrm{VI}}$ for white mica along of the hanging wall and footwall argillites of Koudiat Aïcha. (b) Major oxides profiles of white mica along drill hole KA25 which intersects massive sulphide lenses.
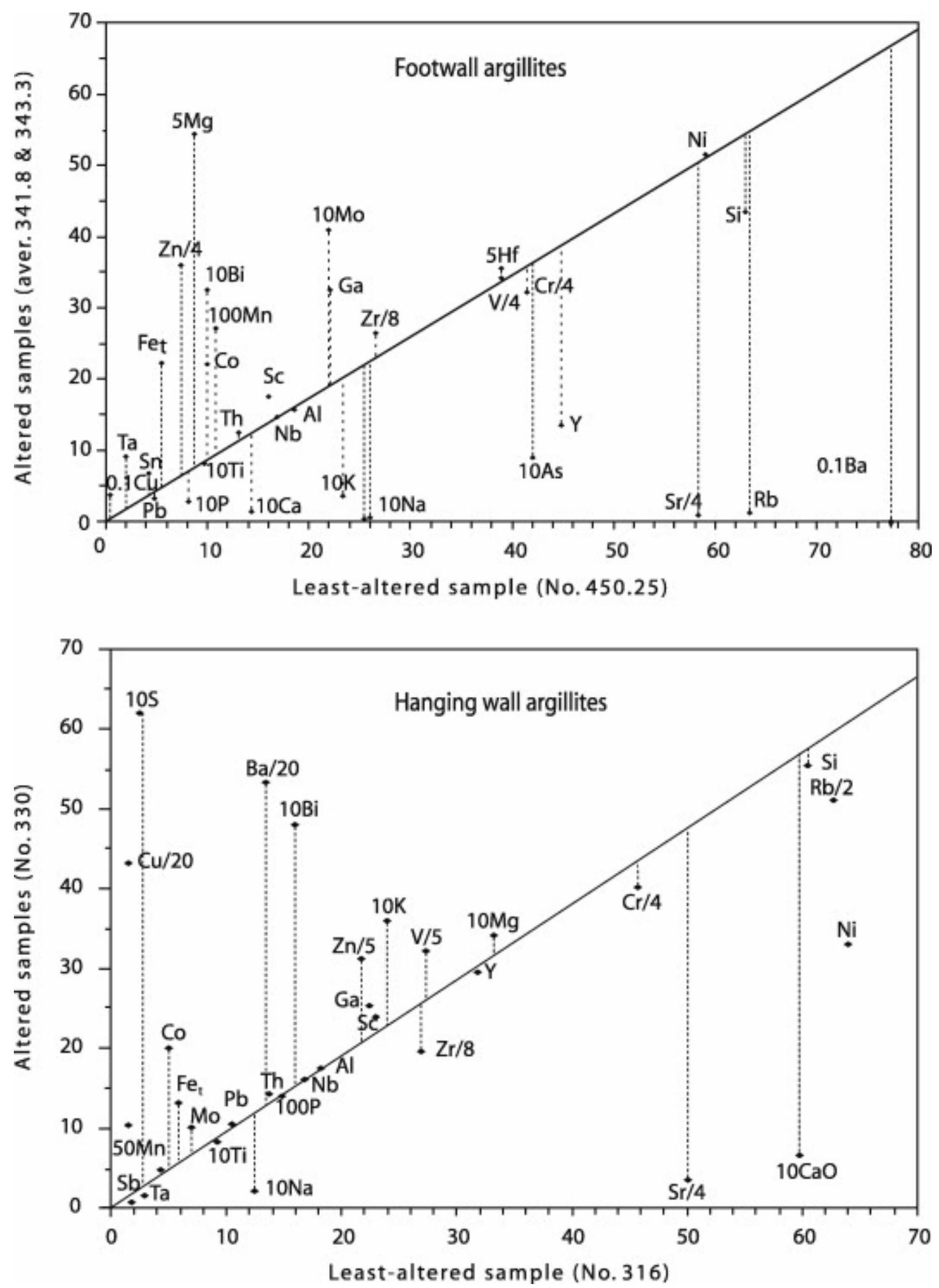

Fig. 15. : Isocon mass-balance diagram (Grant, 1986), comparing the least-altered argillites to altered equivalents within the footwall alteration zone. 


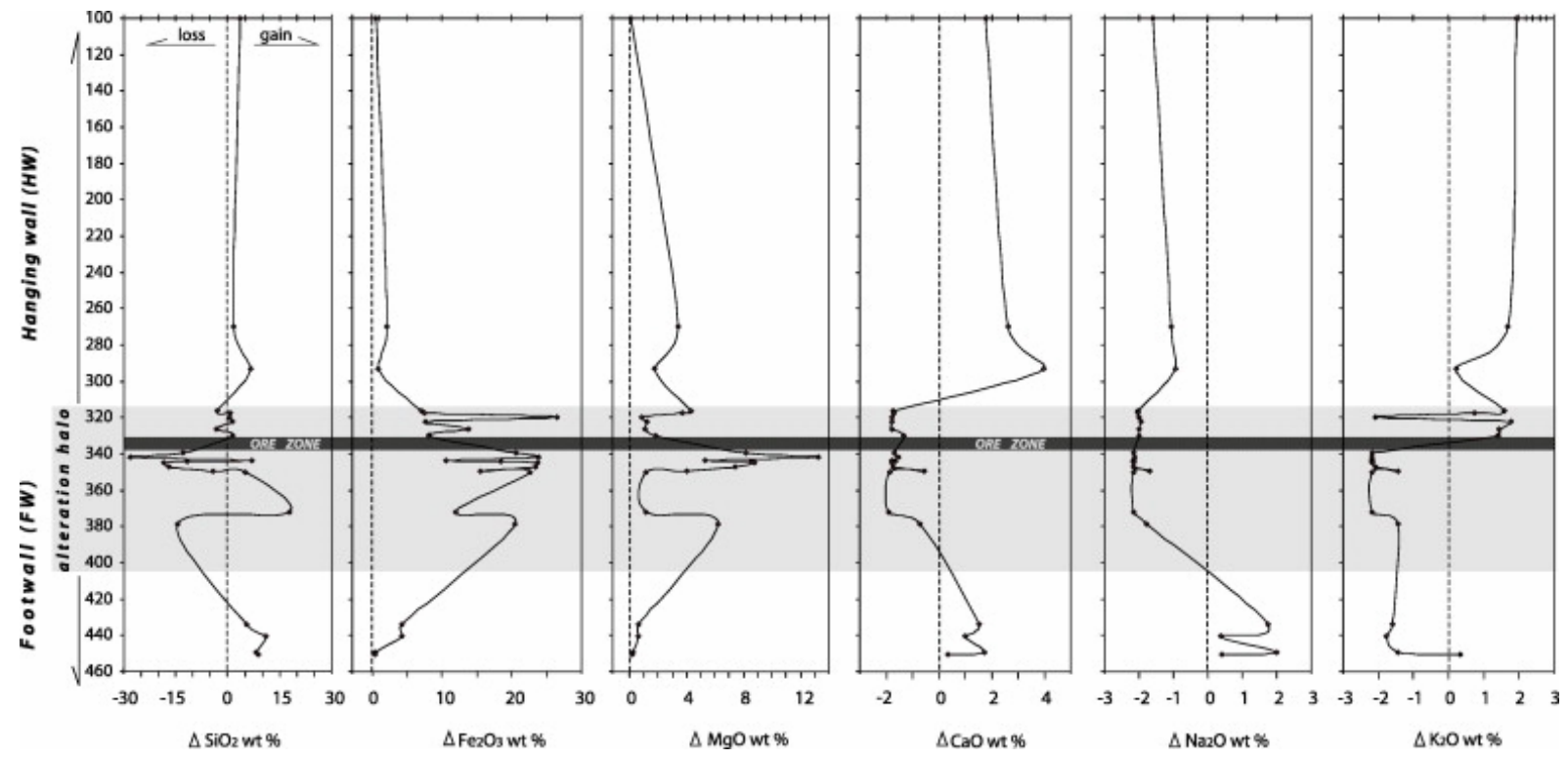

Fig. 16. : Mass-balance down-hole profiles of DDH KA22b. The percentage mass-change (4\%) values were computed using Grant graphs of Fig. 15. 
Table 5. Oxygen and hydrogen isotope compositions of bulk rock and mineral separate samples along DDH KA22b.

\begin{tabular}{|c|c|c|c|c|c|c|}
\hline Sample no. & Description & Mineral & Rock & $\delta^{18} \mathbf{O}_{\text {SMOW }}$ & Approx. $\% \mathrm{H}_{2} \mathrm{O}$ & $\delta \mathbf{D}_{\text {SMow }}$ \\
\hline \multirow[t]{3}{*}{ KA22-5 } & Rhyodacite & wr & 13.7 & 10.6 & 2.0 & -40 \\
\hline & & qtz & 14.6 & 12.5 & & \\
\hline & & qtz-plag & 15.1 & 11.2 & & \\
\hline \multirow[t]{3}{*}{ KA22-6 } & & wr & 14.3 & 10.0 & 2.3 & -40 \\
\hline & & qtz & 14.9 & 11.2 & & \\
\hline & & qtz-plag & 14.6 & 10.3 & & \\
\hline \multirow[t]{3}{*}{ KA22b-48 } & Gabbro & wr & 12.7 & 9.6 & 2.4 & -52 \\
\hline & & $\mathrm{hb}$ & 14.7 & 8.5 & 2.2 & -51 \\
\hline & & plag & 13.7 & 10.2 & & \\
\hline \multirow[t]{2}{*}{ KA22b-317.25 } & Argillite HW & wr & 14.0 & 9.7 & 6.0 & -34 \\
\hline & & qtz-ser & 13.5 & 9.6 & 5.9 & -36 \\
\hline \multirow[t]{2}{*}{ KA22b-330.7 } & & wr & 12.7 & 9.6 & 5.7 & -36 \\
\hline & & qtz-ser & 14.2 & 9.2 & 5.6 & -36 \\
\hline \multirow[t]{2}{*}{ KA22b-345.0 } & & wr & 12.1 & 6.7 & 11.4 & -44 \\
\hline & & qtz-chl & 12.8 & 6.2 & 11.9 & -44 \\
\hline \multirow[t]{2}{*}{ KA22b-350.3 } & & wr & 11.9 & 9.3 & 4.0 & -47 \\
\hline & & qtz-chl & 11.6 & 9.6 & 4.4 & -50 \\
\hline \multirow[t]{3}{*}{ KA22b-362.0 } & Gabbro HW & wr & 13.0 & 8.1 & 3.3 & -51 \\
\hline & & $\mathrm{hb}$ & 13.3 & 8.3 & 3.1 & -51 \\
\hline & & plag & 13.8 & 10.2 & & \\
\hline \multicolumn{7}{|l|}{ Ore zone } \\
\hline KA22b-374.0 & Argillite FW & wr & 13.7 & 8.1 & 7.5 & -39 \\
\hline
\end{tabular}




\begin{tabular}{|c|c|c|c|c|c|c|}
\hline Sample no. & Description & Mineral & Rock & $\delta^{18} \mathbf{O}_{\text {SMOW }}$ & Approx. $\% \mathrm{H}_{2} \mathrm{O}$ & $\delta \mathbf{D}_{\text {SMow }}$ \\
\hline & & qtz-chl & 14.1 & 7.9 & 8.4 & -41 \\
\hline \multirow[t]{3}{*}{ KA22b-408 } & Gabbro FW & wr & 13.3 & 6.9 & 2.9 & -28 \\
\hline & & $\mathrm{hb}$ & 13.2 & 7.7 & 3.1 & -46 \\
\hline & & plag & 14.4 & 11.3 & & \\
\hline
\end{tabular}

Note $: \mathrm{wr}=$ wall rock; $\mathrm{hb}=$ hornblende; $\mathrm{qtz}=$ quartz; $\mathrm{plag}=$ plagioclase $; \mathrm{ser}=$ sericite 

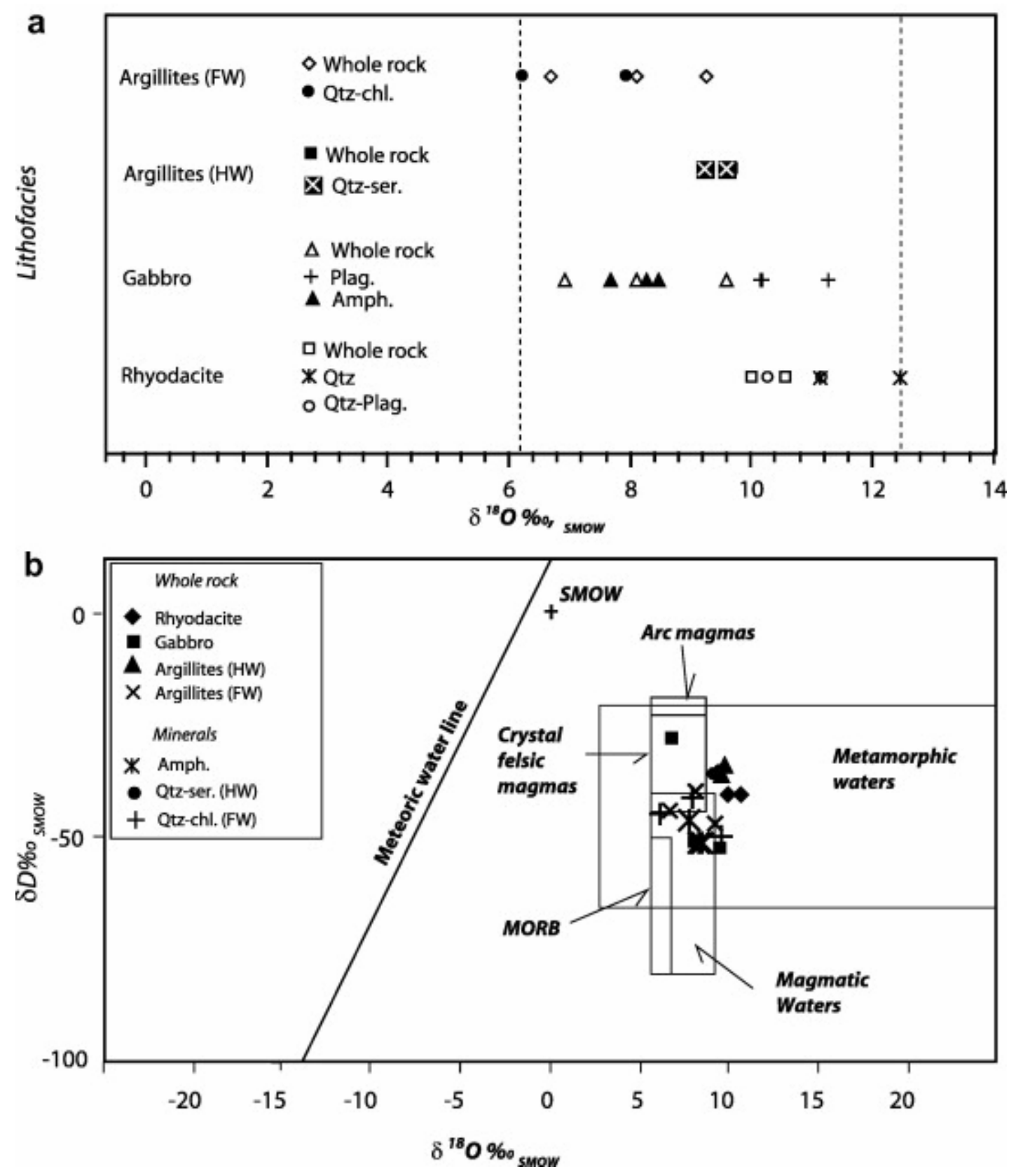

Fig. 17. : (a) Oxygen and hydrogen isotope signatures for Koudiat Aïcha. (b) Schematic projection of $\delta \mathrm{D}_{\text {SMOW }}$ versus $\delta^{18} \mathrm{O}_{\text {SMOW }}$. The meteoric line is after Epstein and Taylor (1970) and the various types of crustal magmas are after Hedenquist and Lowenstern (1994). 